University at Buffalo School of Law

Digital Commons @ University at Buffalo School of Law

10-1-1986

\title{
Transcending Equality Theory: A Way Out of the Maternity and the Workplace Debate
}

Lucinda M. Finley

University at Buffalo School of Law

Follow this and additional works at: https://digitalcommons.law.buffalo.edu/journal_articles

Part of the Civil Rights and Discrimination Commons, and the Law and Gender Commons

\section{Recommended Citation}

Lucinda M. Finley, Transcending Equality Theory: A Way Out of the Maternity and the Workplace Debate, 86 Colum. L. Rev. 1118 (1986).

Available at: https://digitalcommons.law.buffalo.edu/journal_articles/661

This article originally appeared at 86 Colum. L. Rev. 1118 (1986). Reprinted by permission.

\section{IN COPYRIGHT}

This Article is brought to you for free and open access by the Faculty Scholarship at Digital Commons @ University at Buffalo School of Law. It has been accepted for inclusion in Journal Articles by an authorized administrator of Digital Commons @ University at Buffalo School of Law. For more information, please contact lawscholar@buffalo.edu. 


\title{
TRANSCENDING EQUALITY THEORY: A WAY OUT OF THE MATERNITY AND THE WORKPLACE DEBATE
}

\author{
Lucinda M. Finley*
}

There is a natural temptation to escape if we can, to close the door behind us on this despised realm which threatens to engulf all women, whether as mothers, or in marriage, or as the invisible, ill-paid sustainers of the professionals and social institutions. There is a natural fear that if we do not enter the common world of men, as asexual beings or as "exceptional" women, do not enter it on its terms and obey its rules, we will be sucked back into the realm of servitude, whatever our temporary class status or privileges. This temptation and this fear compromise our powers, [and] divert our energies ....

$[F]$ eminism means finally that we renounce our obedience to the fathers and recognize that the world they have described is not the whole world. Masculine ideologies are the creation of masculine subjectivity; they are neither objective, nor value-free, nor inclusively "human." Feminism implies that we recognize fully the inadequacy for us, the distortion, of male-created ideologies, and that we proceed to think, and act, out of that recognition. ${ }^{1}$

\section{INTRODUCTION}

There is a persistent, deeply entrenched ideology in our society, and in the legal system reflecting that society, that men and women perform different roles and occupy different spheres. The male role is that of worker and breadwinner, the female role is that of childbearer and rearer. The male sphere is the public world of work, of politics, and of culture-the sphere to which our legal and economic systems have been thought appropriately to be directed. The female sphere is the private world of family, home, and nurturing support for the separate public activities of men. ${ }^{2}$ Traditionally in our culture, legal inter-

* Associate Professor of Law, Yale Law School. J.D., 1980, Columbia Law School.

I have benefitted immensely from presenting an earlier draft of this Article at the University of Pennsylvania Legal Studies Workshop, the Yale Law School Faculty Workshop, and the Femcrits Workshop in Cambridge, Massachusetts. Numerous friends and colleagues have provided helpful comments, but several people deserve special mention for their contributions of attention, encouragement, or inspiration: thanks to Drew Days, Clare Dalton, Don Elliott, Mary Joe Frug, Jack Getman, Carol Gilligan, Chris Desan Husson, Jay Katz, Jean Love, Carrie Menkel-Meadow, Gary Minda, Martha Minow, Andy Tomback, and all the wonderful students in the Women and the Law seminar I taught with Jay Katz in the fall semester of 1985.

1. A. Rich, Conditions for Work: The Common World of Women, in On Lies, Secrets, and Silence 206-07 (1979).

2. The public-private distinction appears in many other contexts. Moreover, some things, like the workplace, can be either public or private depending on the context. For 
vention in this private sphere has been viewed as inappropriate or even dangerous. ${ }^{3}$ The notion that the world of remunerative work and the world of home-or the realms of production and reproduction-are -separate, has fostered the economic and social subordination of women in two interrelated ways. First, the values necessary for success in the home world, such as nurturing, responsiveness to others' needs, and mutual dependence, have been viewed as unnecessary, even incompatible with the work world. Since the work world is assigned economic importance, the traditionally "female" tasks and qualities of the home world have come to be generally devalued in our society. ${ }^{4}$ Second, the separateness of the public and private worlds, and the consignment of women to the home world, is seen as natural, based on unquestioned assumptions stemming from the apparent immutability of roles derived from different reproductive capacity.

The fact that women bear children and men do not has been the major impediment to women becoming fully integrated into the public world of the workplace. The lack of integration of women into the public world has made the workplace unresponsive to values such as interconnectedness and concern for the needs of others. This unresponsiveness not only perpetuates barriers to the participation of women in the economically valued work world, it also denies men opportunities to participate more meaningfully in the home world. Assumptions and stereotypes about the physical and emotional effects of pregnancy and motherhood, about the appropriate role of women in society stemming from the physical fact of childbearing, and about the perceived response of women to childbearing, have contributed more than any other factor to the discriminatory treatment of women in the workplace and to the maintenance of the ideology of separate spheres. ${ }^{5}$

example, in relation to the government, the workplace is usually considered the "private" sector, but in relation to the home, it is part of the "public" world. When I use the terms "public" and "private" in this Article, I am referring to the apparent dichotomy between the worlds of work and family.

3. For in-depth explorations of how the law has operated differently in each sphere, thus helping to maintain the public-private distinction and its impact on the status of women, see K. O'Donovan, Sexual Divisions in Law (1985); Olsen, The Family and the Market: A Study of Ideology and Legal Reform, 96 Harv. L. Rev. 1497 (1983); Polan, Toward a Theory of Law and Patriarchy, in The Politics of Law 294 (D. Kairys ed. 1982).

4. Cf. J. Martin, Reclaiming a Conversation (1985) (exploring educational philosophy to demonstrate that the purpose of education has been to prepare people for the public world of production, thereby ignoring and devaluing the skills and qualities associated with the home world of reproduction).

5. Taub \& Schneider, Perspectives on Women's Subordination and the Role of Law, in The Politics of Law 117 (D. Kairys ed. 1982). As one commentator has noted, "it is fair to say that most of the disadvantages imposed on women, in the workforce and elsewhere, derive from this central reality of the capacity of women to become pregnant and the real and supposed implications of this reality." Discrimination on the Basis of Pregnancy, 1977: Hearings on S. 995 Before the Subcomm. on Labor of the Senate Comm. on Human Resources, 95th Cong., 1st Sess. 123 (1977) (remarks of Prof. Wendy Williams). But see MacKinnon, Feminism, Marxism, Method, and the State: An Agenda 
The characterization of the separate spheres has become less a description of everyday life than one of a persistent ideology. The publicprivate dichotomy is entrenched in and fostered by our legal system. In the context of pregnancy and the workplace, this is illustrated by the judicial tolerance of excluding pregnancy from disability or other benefit plans, ${ }^{6}$ by the fact that women still can be legally fired from certain jobs when they become pregnant, ${ }^{7}$ by the difficulty pregnant women or new mothers have in some states in obtaining unemployment compensation, ${ }^{8}$ and by the general lack of adequate pregnancy and maternity leave and benefit policies in this country. ${ }^{9}$ The result is that many women are forced out of the workplace and into the home when they give birth, are denied economic opportunities because of their childbearing role, or are forced back into the workplace sooner than sound child development policy would dictate in order to preserve job rights. ${ }^{10}$ This situation reinforces the notion that the home and the workplace are incompatible worlds, that women and men must choose between them, and that women's needs, interests, or perspectives must inevitably give way to the male-defined needs and interests of the workplace.

Our legal system also reinforces the ideology of separate spheres through its use of a doctrinal framework-equality or antidiscrimination-which founders on the differences presented by pregnancy and maternity. This doctrinal framework is incapable of challenging the underlying structures of institutions and the way in which these structures perpetuate barriers to the integration of home lives and work lives for both men and women. It leaves unquestioned the notion that life patterns and values that are stereotypically male are the norm, such as the idea that competitiveness and focus on work to the exclusion of other concerns is necessary to the productive functioning of the workplace. It leaves unexamined the assumption that it would cost too much, in terms of money or productivity, for an employer to make it possible for workers of both sexes to better integrate family responsibilities with job commitments.

Most feminists agree that one of the crucial issues to be addressed

for Theory, 7 Signs 515 (1982) (contending that the way in which men have defined female sexuality and have turned women into objects of sexual desire is the most signifcant contributing factor to the oppression of women).

6. See infra note 21 and accompanying text.

7. See infra notes $60-64$ and accompanying text.

8. See infra note 24 and accompanying text.

9. For a description of maternity policies in the United States and an analysis of their inadequacy, see S. Kamerman, A. Kahn \& P. Kingston, Maternity Policies and Working Women (1983) [hereinafter Maternity Policies]; see also Catalyst, Preliminary Report on a Nationwide Survey of Maternity/Parental Leaves, Perspective \# 17 (June 1984) (survey of leave policies of top Fortune 500 corporations) [hereinafter Catalyst]; S. Hewlett, A Lesser Life (1986) (describing effects of absence of maternity leave policies).

10. See infra note 23 and accompanying text. 
in order to eliminate the economic and social subordination of women how is to make the workplace more accommodating to pregnancy and parenting needs. Although legislation has overturned the most egregious example of judicial blindness to the link between workplace pregnancy policies and the subordinate economic status of women, ${ }^{11}$ many examples of the persistence of stereotypes about the special vulnerability of pregnant women and their suitability for certain jobs can still be found in judicial decisions and in employer policies. Despite agreement on the ultimate goal, feminists are deeply divided over how best to eliminate the biases that pregnant women face in retaining either their jobs or a reasonable degree of economic security while pregnant and during their babies' early months. This division, which has become known as the special treatment/equal treatment debate, ${ }^{12}$ focuses on state laws requiring employers to provide reasonable maternity leave even if they do not generally provide illness or disability leave. ${ }^{13}$

My purpose in this Article is not to join the special treatment/equal treatment debate, because, as I will show, I think that in significant respects the arguments of each side are both correct and flawed. Rather, the debate is used principally to critique the usefulness of equality analysis as a transformative device for challenging the social and economic subordination of women. This debate, when understood as one between two competing strains of equality doctrine, will also illuminate the ways in which equality analysis avoids an examination of the deeper roots of the problem of gender hierarchy. ${ }^{14}$ In the process, the Article

11. The Pregnancy Discrimination Act of 1978, 42 U.S.C. $\$ 2000 \mathrm{e}(\mathrm{k})$ (1982), overruled the Supreme Court's decision in General Elec. Co. v. Gilbert, 429 U.S. 125 (1976), that the exclusion of normal pregnancy and associated illnesses from a company's disability benefit plan was not sex-based discrimination.

12. For leading examples of each position, see Krieger \& Cooney, The Miller-Wohl Controversy: Equal Treatment, Positive Action and the Meaning of Women's Equality, 13 Golden Gate U. L. Rev. 513 (1983) (advocating special treatment, or positive action approach); Williams, Equality's Riddle: Pregnancy and the Equal Treatment/Special Treatment Debate, 13 N.Y.U. Rev. L. \& Soc. Change 325 (1985) (defense of equal treatment position) [hereinafter Williams, Equality's Riddle].

The debate has crystallized around court challenges to the California and Montana maternity leave laws. See California Fed. Sav. \& Loan Ass'n v. Guerra, 758 F.2d 390 (9th Cir. 1985), cert. granted, 106 S. Ct. 783 (1986); Miller-Wohl Co. v. Commissioner of Labor \& Indus., 692 P.2d 1243 (Mont. 1984), petition for cert. filed, 106 S. Ct. 777 (1985).

13. See infra note 49 and accompanying text.

14. By gender hierarchy I mean the fact that men, more often than women, hold positions of power and economic influence, that men on the whole are economically better off than women in this society and have access to more economic opportunities, and that values and traits associated with males are considered more desirable, but often only when held by men. While the term "gender hierarchy" is certainly a loaded one, I use it to avoid the phrase "gender inequality." That latter phrase, in my view, conjures up a limited vision of the problem and what is necessary to eradicate it. The tendency in using the tag "inequality" to treat women's experience merely in terms of the need to increase their opportunities to be more like men is part of what I critique in this Article. 
will also touch on an examination of some of these deeper roots; namely, the separate spheres ideology, the place of women's ability to bear children in maintaining that ideology, and the corresponding assumptions about pregnancy and women's role in society that have fueled workplace maternity policies. ${ }^{15}$ Each of these related aspects of the problem of accommodating the workplace to family needs are not, and cannot, be embraced by equality analysis.

In moving towards a more satisfactory framework than traditional equality analysis, this Article will first review the assumptions, stereotypes, and values underlying pregnancy and maternity policies and judicial and legislative approaches to them. The purpose of this review will be to understand the context and importance of the state laws requiring the availability of maternity leave and the legal debate they have engendered. The Article will then summarize the special treatment/equal treatment debate, and use it to critique equality analysis. Finally, the Article will suggest the contours of a new approach to gender issues based on a richer conception of human nature and needs than the view of humans as atomized individuals who are, or can be, the same, that has defined our thinking about rights and equality under our system's traditional legal framework.

\section{Maternity and the Workplace-The Assumption of Incompatibility and the Policies that have Made it True}

The assumption that men and women naturally and biologically occupy different roles in life has led to an array of rules and practices in the public, "male" world of the workplace that have effectively forced women into the home when they signalled they were ready to assume their "natural" role by getting married or by becoming pregnant. The legal system's continuing tolerance of these policies has reinforced the underlying assumption that being a worker and being a mother, or an actively involved parent, are inherently incompatible roles. This assumption has worked to the detriment of both men and women. Because women could not participate, or were penalized for their efforts to participate in the workplace once they became pregnant, they often had to leave it out of necessity rather than choice. But, because they left, employers and legal policymakers justified exclusion and the lack of accommodation by claiming that women sever their connection with the workplace once they choose to become mothers. ${ }^{16}$ Men too have

15. The problems of gender hierarchy and the separate spheres ideology are inextricably linked. See K. O'Donovan, supra note 3; Olsen, supra note 3. By questioning the idea of home and work as separate spheres, we can start to eliminate gender hierarchy. At the same time, concern about eliminating gender hierarchy must lead us to question the ideology of separate spheres.

16. The assumption that women will leave the work world at pregnancy continues even today. For example, during congressional hearings on the Pregnancy Discrimina- 
been harmed because the women who bear their children lose pay, benefits, or job protection, and because they have been pushed by societal values and workplace structures into being relatively uninvolved with the rearing of their children.

\section{A. Employer Policies and Attitudes}

Until the last twenty years or so, many employers either would not hire married women, or would not hire married women with young children. ${ }^{17}$ When women workers became pregnant, they faced a range of adverse consequences. Often, it was simply understood that they would quit, and the lack of any maternity leave policies usually assured that this would be so. ${ }^{18}$ Other women were fired, or relegated to less desirable jobs. ${ }^{19}$ Little more than a decade ago, many women faced

tion Act, employers expressed concern that women would abuse leave, by taking long maternity leaves at the employer's expense when they actually had no intention of returning to work. Maternity Policies, supra note 9 , at 44 .

17. See A. Kessler-Harris, Out to Work: A History of Wage Earning Women in the United States 234-35, 254-59, 296-97 (1982); L. Weiner, From Working Girl to Working Mother: The Female Labor Force in the United States, 1820-1980, at 98-118 (1985); see also Hartley v. Brotherhood of Ry. \& S.S. Clerks, 283 Mich. 201, 277 N.W. 885 (1938) (upholding the alteration of a collective bargaining agreement providing that layoffs be according to seniority when, after receiving complaints that married women were being retained while men were laid off, the union and the company changed the contract to discharge all married women). As recently as 1971, the Supreme Court indicated that evidence that a woman's childcare responsibilties affected her job performance in ways that a man's having children did not could justify, under title VII, an employer's policy of refusing to hire women with pre-school children. Phillips v. Martin Marietta Corp., 400 U.S. 542 (1971). Since the 1970's, employer policies placing restrictions on hiring married women or mothers have largely disappeared under the pressure of title VII, changes in the economy, and the changing composition of the labor force. In $1982,53 \%$ of all employed women were married, and $51 \%$ of married women were employed. Fifty-six percent of married mothers were in the workforce, and $61 \%$ of divorced or single mothers were employed. Ferree, Sacrifice, Satisfaction, and Social Change: Employment and the Family, in My Troubles Are Going to Have Trouble With Me: Everyday Trials and Triumphs of Women Workers 61 (K. Sacks \& D. Remy eds. 1984).

18. In Maternity Policies, supra note 9 , at $1-2$, the authors recount the experience of a woman who became pregnant in 1947 and quit her job without even bothering to ask her boss for permission to continue working, since it was mutually understood that women would stop working when they became pregnant. This understanding is one of the reasons for the general lack of leave policies and benefits. See also id. at 33-38 (recounting attitudes and policies regarding pregnant women in the workplace). A 1964 Bureau of Labor Statistics Study showed that married women under 35 most frequently reported pregnancy as the reason they quit work. Bureau of Labor Statistics, U.S. Dep't of Labor, Special Labor Force Report No. 59, Why Women Start and Stop Working: A Study in Mobility 1080 (1965).

19. Maternity Policies, supra note 9 , at 33-36. The airline industry provides a good illustration of these phenomena. Women flight attendants traditionally were either fired when they became pregnant, or were transferred to less desirable ground positions, often with a loss of seniority or pay. See, e.g., Levin v. Delta Air Lines, 730 F.2d 994 (5th Cir. 1984); Harriss v. Pan Am. World Airways, 649 F.2d 670 (9th Cir. 1980); 
mandatory maternity leaves that were unrelated to their ability or desire to work and that adversely affected their benefits and future job prospects. ${ }^{20}$ Those women who wanted to challenge the assumption that impending motherhood meant leaving the workplace met with penalties such as the loss of job benefits including sick leave, disability or health insurance coverage, and seniority. ${ }^{21}$ This loss of benefits signalled that no matter what the woman's intention, the employer regarded her as no longer part of the workforce. Indeed, the denial of benefits was sometimes justified by employers on the ground that they assumed women would not return to the workforce after having their babies. ${ }^{22}$ For those women who did want to return to work, but also wanted to spend some time solely being a new mother, inadequate leave policies often meant returning to work sooner than medically or emotionally optimal in order to receive needed income or to retain economically essential benefits. ${ }^{23}$ While on leave, usually without income, women in some states found that they could not receive unemployment

Burwell v. Eastern Airlines, 633 F.2d 361 (4th Cir. 1980) (en banc), cert. denied, 450 U.S. 965 (1981). These forced interruptions in women's labor force participation are closely related to the wage depression that usually accompanies women's jobs. See, e.g., A. Kessler-Harris, supra note 17 , at 312-14.

20. During the 1940's, the Women's Bureau of the U.S. Department of Labor recommended that pregnant women refrain from working starting six weeks before delivery and continuing for two months after. Women's Bureau, Office of the Secretary, U.S. Dep't of Labor, Bulletin No. 240, Maternity Protection of Employed Women 7 (1952). Several states adopted laws based on this recommendation, prohibiting employers from allowing women to work for a certain period of time before and after childbirth, for the sake of maternal and child health. The Women's Bureau conceded that since few leaves were given with job security or wage replacement, women were "protected" right out of their jobs. Id. at 24; see Williams, Equality's Riddle, supra note 12, at 334 . During the 1970 's the Supreme Court struck down as a violation of due process a mandatory leave policy because it created an irrebuttable presumption of inability to work unrelated to individual capacity. Cleveland Bd. of Educ. v. LaFleur, 414 U.S. 632 (1974).

21. See, e.g., Nashville Gas Co. v. Satty, 434 U.S. 136 (1977) (loss of seniority and denial of sick leave); General Elec. Co. v. Gilbert, 429 U.S. 125 (1976) (denial of disability insurance benefits to pregnant women); Holthaus v. Compton \& Sons, Inc., 514 F.2d 651 (8th Cir. 1975) (pregnant worker discharged, whereas others suffering temporary disabilities unrelated to pregnancy not discharged); Hutchison v. Lake Oswego School Dist., 519 F.2d 961 (9th Cir. 1975) (pregnancy or childbirth-related disabilities excluded from sick-leave policy), vacated and remanded, 429 U.S. 1033 (1977).

22. See Maternity Policies, supra note 9 , at $33,44,73-74$.

23. Id. at 63-72, 99-132. Although this observation may seem anomalous in light of the argument that pregnancy policies have harmed women's participation in the workforce, a forced premature return to work can have adverse consequences for a woman's employment future. Under these circumstances, new mothers may need to take a lot of sick leave, or may be unable to concentrate as well or to perform as well on the job because of stress, fatigue, and illness. This may cause a woman to be fired or denied promotions or merit increases, whereas if adequate recuperation time had been guaranteed to her, she would not have had these black marks on her record. See, e.g., Lang, Research: Child Care Policies, Yale Magazine, Sept. 1985, at 44. A forced, premature return to work is consistent with the home/work dichotomy because being forced out of the home world in order to retain job benefits is another indication of how workplace 
compensation, because the state defined them as unable to work by the very fact of their new motherhood. ${ }^{24}$

Both employers' policies and the law have been very slow in catching up to the reality that women now comprise over $44 \%$ of the workforce. ${ }^{25}$ Women are projected to make up half of the workforce by 1990.26 Half of all mothers with pre-school aged children are in the workforce, ${ }^{27}$ and $85 \%$ of women workers can be expected to bear at least one child during their years of workforce participation. ${ }^{28}$ Despite these numbers, maternity or parental leave policies in the United States lag far behind the rest of the industrialized world, especially among smaller employers and in the service or retail industries where most women workers are found.29 The Pregnancy Discrimination Act amendment to title VII, ${ }^{30}$ which is based on the equal treatment approach, ${ }^{31}$ has brought vast improvement in the availability of benefit coverage for pregnancy. ${ }^{32}$ Nonetheless, this law is limited because it requires employers to make available to pregnant women only what they make available to men for other conditions. Consequently, it tolerates a wide variety in policies. Those which are inadequate to offer meaningful protection for a variety of human conditions that keep both men and women out of work are just as acceptable as more generous policies.

Abbreviated leave policies have a particularly harsh impact on women who become pregnant or have young children. On average in the United States, most women are entitled to no more than six to eight weeks of pre- and post-natal leave. ${ }^{33}$ Those women whose employers make no special provisions for maternity leave but allow women to use

policies make it difficult, if not impossible, to devote sufficient energy and attention to one role without losing something in the other role.

24. These policies have recently been challenged in courts. See, e.g., Turner v. Department of Employment Sec., 423 U.S. 44 (1975); Brown v. Porcher, 660 F.2d 1001 (4th Cir. 1981), cert. denied, 459 U.S. 1150 (1983); Connecticut Nat'l Org. for Women v. Peraro, Civ. Action No. N77-477 (D. Conn. Apr. 8, 1980) (consent decree forbidding various state agencies from declaring women who are recovering from delivery, who are breast feeding, or who have young children not yet in child care, as unable to work and thus ineligible for unemployment compensation); Wimberly v. Labor \& Indus. Relations Comm'n, 688 S.W.2d 344 (Mo. 1985), cert. granted, 106 S. Ct. 1633 (1986); Williams, Equality's Riddle, supra note 12 , at 334 .

25. Maternity Policies, supra note 9, at 7-9; Williams, Equality's Riddle, supra note 12 , at 352 n.111.

26. Maternity Policies, supra note 9, at 7-9; Williams, Equality's Riddle, supra note 12 , at 352 n.111.

27. Maternity Policies, supra note 9 , at 8-9.

28. Id. at 5 .

29. See id. at $14-15,56-58,155-56$.

30. 42 U.S.C. $\S 2000 \mathrm{e}(\mathrm{k})(1982)$.

31. For a discussion of the strategy grounding the amendment in the equal treatment approach, see infra notes 118-19 and accompanying text.

32. See Catalyst, supra note 9 , at 6 ; Maternity Policies, supra note 9, at 59, 63 .

33. Maternity Policies, supra note 9 , at 56-59, 117-20. 
other sorts of leave to cover their time off may have even less available leave time. Many employers restrict eligibility for benefits such as illness or disability leave, personal leave, or vacation to employees with requisite seniority. Thus, many women in their first year of employment may have virtually no routes for taking maternity leave. ${ }^{34}$ When leave is available it is rarely with full pay, and partial wage replacement, when it exists, is usually for less than the allowed leave time. ${ }^{35}$ Depending on how the employer classifies the leave, women may not be entitled to continue crucial benefits such as health insurance. ${ }^{36}$ Women who must take their maternity leave as sick leave may return to find themselves marked as excessively sick or absent. ${ }^{37}$ This jeopardizes their job futures precisely at the time when they are likely to need more use of sick leave either to cope with their own fatigue or their babies' illnesses. ${ }^{38}$

Despite the changed composition of the workforce, the structures of the workplace remain built either around the needs of male management, or the assumption that the typical worker is a man with a wife at home to worry about the demands of the private sphere. Thus, when women return to work, they often find that workplace structures are utterly insensitive to the reality of a worker with both home and job responsibilities. ${ }^{39}$ Child care arrangements are still generally regarded as a woman's private problem, of no concern to the employer. This view persists despite the way in which child care availability affects a parent's, and especially a mother's, work life. ${ }^{40}$ Flexible job scheduling is less rare, although still far from common. Most workplaces remain

34. Id. at 59-60. Lack of sick leave during the probationary period of initial employment caused Tamara Buley, a sales clerk for the Miller-Wohl company, to lose her job when she became pregnant and set off the Miller-Wohl litigation at the center of the special treatment/equal treatment debate. See Krieger \& Cooney, supra note 12, at 513; see also Abraham v. Graphic Arts Int'l Union, 660 F.2d 811 (D.C. Cir. 1981) (rule allowing only 10 days sick leave to temporary employees found to have disparate impact on pregnant women).

35. Maternity Policies, supra note 9 , at 67-73, 111-20.

36. Id. at $105-11$.

37. Id. at 112-13.

38. Id. Most firms view employees who are excessively sick unfavorably. Those who are listed as absent due to sickness far more than others during a given period, regardless of past use of sick leave, tend to lose their jobs or are otherwise penalized. Thus, listing a pregnancy leave as sick leave can have dire, unanticipated job consequences for women.

39. For a comprehensive discussion of the way in which workplace structures and attitudes have an adverse economic and social impact on working mothers, see Frug, Securing Job Equality for Women: Labor Market Hostility to Working Mothers, 59 B.U.L. Rev. 55 (1979).

40. See, e.g., id. at 57; Taub, From Parental Leaves to Nurturing Leaves, 13 N.Y.U. Rev. L. \& Soc. Change 381 (1984-85). There are signs of change developing in corporate attitudes. Currently, nearly 2000 mostly large companies, triple the number since 1982, provide some form of corporate child-care assistance for male and female workers. These companies are finding that making childcare available reduces worker absen- 
structured around an eight-hour day, five days a week, even though such a schedule conflicts with employees' needs to do shopping and errands, to attend children's school functions or doctor's appointments, to be available to children when they are out of school, or to meet similar needs of other dependents. ${ }^{41}$ There is nothing inevitable or natural about this particular workplace structure. ${ }^{42}$ Together with the inadequacy of maternity policies, the structure of the workplace demonstrates the ways in which employers still remain tied to the notion that the typical worker is someone-a man-who does not have to worry about bearing or rearing children or nurturing other dependants. Employers have too readily assumed that only the existing ways of doing things can satisfy their needs. Consequently, both the definitions of their needs and the inevitability of existing structures have too rarely been subject to reexamination and rethinking.

Women's roles as wives and mothers continue to influence the expectations of employers. It is still often assumed that these roles create a conflict of allegiance between home and work so that women who try to accommodate the two spheres are seen as demonstrating a lack of commitment to the work world. ${ }^{43}$ To cope with what is often an open conflict in expectations, many women take part-time jobs, which leave them with inadequate income and no benefits. ${ }^{44}$ Others constrict the types of jobs or locations of jobs that they hold. ${ }^{45}$ This assumption of conflicting responsibilities has caused many women to be shunted into

teeism and turnover, increases productivity, and enhances recruiting. Bruno \& Vehling, Day Care on the Job, Newsweek, Sept. 2, 1985, at 59-62.

41. These structures have a particularly adverse impact on women. See, e.g., Frug, supra note 39 ; Taub, supra note 40 , at 383 .

42. Indeed, the modern workplace structure is of fairly recent vintage. Before the 1930 's, working days that ranged from twelve to fourteen hours six days a week, were the norm. Employers fought legislation that reduced to ten or twelve the number of hours women or children could work by defending the necessity of the longer work day. See A. Kessler-Harris, supra note 17, at 180-95, 201-02. Just as employers adapted to the now prevalent eight-hour day and five-day week, it would seem they could survive under alternative hour and day structures.

43. Coser \& Rokoff, Women in the Occupational World: Social Disruption and Conflict, in Women and Work: Problems and Perspectives 39-53 (R. Kahn-Hut, A. Daniels \& R. Colvard eds. 1982). The assumption of lack of career commitment can be a forbidding hurdle for women in traditionally male-dominated professions such as law. See, e.g., Frug, supra note 39 , at $60,70-74$. A recent article on law firm maternity and part-time work policies in the American Lawyer graphically portrays how pervasive the assumption of mutual exclusivity between home demands and commitment to career still is. The article quotes managing partners from major firms who discourage less than full time (which in a law firm means considerably more than forty hours per week) work by women with young children because "women have to choose between motherhood and the firm. After all, they went to law school for a career."; and "with the kind of highpressure work we do, we can't encourage a less than full time commitment." Brill, Labor Pains, The American Lawyer, Jan.-Feb. 1986, at 1, 13.

44. Frug, supra note 39 , at 57-58.

45. Id. 
"women's jobs," where employers expect high turnover and thus view workers as fungible. ${ }^{46}$ Unfortunately, however, these jobs also tend to provide the least flexibility for juggling competing demands. They also pay the least and offer the poorest benefits. ${ }^{47}$ The coerced choice of many women to restrict their labor force participation ${ }^{48}$ has further reinforced the assumption that there is an inherent clash in the roles of mother and worker justifying women's relegation to the private sphere.

\section{B. Assumptions Underlying Pregnancy Policies}

Four states-California, Connecticut, Massachusetts, and Montana-have sought to alleviate some of the barriers facing women workers who become pregnant by enacting laws that require employers to provide "reasonable maternity leaves and benefits." 49 These statutes have sparked the special treatment/equal treatment controversy. The laws in Montana and California have been challenged in court as violating, and thus being pre-empted by, title VII and the Pregnancy Discrimination Act, on the ground that they give more favorable treatment to pregnant women than to other workers who may be physically unable to work. ${ }^{50}$ To understand this debate and the fears it ignites on both sides, it is necessary first to explore the assumptions and biases

46. Coser \& Rokoff, supra note 43 , at $46-48$; Frug, supra note 39 , at 57-58.

47. Frug, supra note 39 , at $57-58$.

48. The restricted labor force participation of women has also contributed to wage depression and the feminization of poverty, because part-time work overwhelmingly is lower paid and unaccompanied by benefits and health insurance. Moreover, women have been disproportionately grouped into occupations that offer little opportunity for advancement. See H. Scott, Working Your Way to the Bottom: The Feminization of Poverty 24-30 (1984); Frug, supra note 39, at 57-58.

49. Cal. Gov't Code $\S 12945$ (b)(2) (West 1980) (leave of up to four months must be provided); Conn. Gen. Stat. Ann. §§ 46a-60(a)(7) (West Supp. 1986) (employers may not terminate a woman on account of pregnancy and must grant reasonable leaves of absence for disability resulting from pregnancy; women must be guaranteed same or comparable job on return); Mass. Gen. L. Ann. ch. $149 \S 105 \mathrm{D}$ (West 1976) (employers must provide nonprobationary employees with eight weeks of job protected seniority and maternity leave, with retention of benefits); Montana Maternity Leave Act, Mont. Code Ann. § 49-2-310, -311 (1985) (illegal to fire women on account of pregnancy or to fail to provide reasonable maternity leave; women must be restored to same or comparable job).

In addition, the agencies charged with implementing anti-discrimination laws in five states-Hawaii, Illinois, New Hampshire, Ohio, and Washington-have adopted regulations requiring maternity leave with job security. See Hawaii Dep't of Indus. \& Lab. Rel. Reg. $\S \S 12-23-56-58$, Act of Nov. 15, 1982, [8A Fair Empl. Prac. Man.] Lab. Rel. Rep. (BNA) 453:2328; 56 Ill. Admin. Code $\S 5210.110$, Act of Nov. 14, 1985, [8A Fair Empl. Prac. Man.] Lab. Rel. Rep. (BNA) 453:2764; N.H. Comm'n on Human Rights, HUM 402.03, as amended Nov. 15, 1984, [8A Fair Empl. Prac. Man.] Lab. Rel. Rep. (BNA) 455:2464; Ohio R. \& Regs. of Ohio Civ. Rights Comm'n, Rule 4112-5-05(G), Act. of Nov. 4, 1971 as amended Dec. 23, 1979, [8A Fair Empl. Prac. Man.] Lab. Rel. Rep. (BNA) 457:268; Washington St. Human Rights Comm'n, WAC 162-30-020(5)(b)-(c), as amended Oct. 28, 1973, [8A Fair Empl. Prac. Man.] Lab. Rel. Rep. (BNA) 457:2952.

50. California Fed. Sav. \& Loan Ass'n v. Guerra, 758 F.2d 390 (9th Cir. 1985), cert. 
underlying societal and employer attitudes and the judicial evaluation of policies that affect women because of their childbearing capacity. ${ }^{51}$ These underlying assumptions have prompted the legal reform strategy that urges the equal treatment, or comparison with men, approach of the Pregnancy Discrimination Act. ${ }^{52}$ At the same time, these persistent assumptions suggest why the equal treatment strategy is inevitably limited in its ability to work on the underlying roots of the problem.

1. The Natural Roles Ideology.-The ideology of separate spheres built on natural roles has fostered both penalization of and paternalism towards women. Underlying both the burdens and the protections has been an assumption that women's biological destiny incapacitates them as workers in the public sphere. This assumption of incapacity goes deeper than the view that mother and worker are inherently clashing roles, or that women's primary responsibility is to the home world. It has caused women to be viewed as either especially vulnerable, in need of protection from the rigors and dangers of work for the good of the human race, or as unsafe and unreliable workers who must be excluded from certain jobs lest they endanger others.

a.Vulnerability and Special Protection.-Assumptions about the natural vulnerability of women are illustrated by the now infamous nineteenth century Supreme Court pronouncements in Bradwell v. Illinois, ${ }^{53}$ and Muller $v$. Oregon. ${ }^{54}$ In Bradwell, Justice Bradley justified the exclusion of a woman from the legal profession with the apparently self-evident assertion that " $[t]$ he natural and proper timidity and delicacy which belongs to the female sex evidently unfits it for many of the occupations of civil life." 55 In Muller, the Court sustained legislation limiting women to a maximum of ten hours of work in laundries, even though at the time such limitations on men's hours were unconstitutional. ${ }^{56}$ The Court rationalized this disparity of treatment by finding it obvious " $[t]$ hat woman's physical structure and the performance of maternal functions place her at a disadvantage in the struggle for subsistence .... This is especially true when the burdens of motherhood are upon her." ${ }^{57}$ Protective legislation such as the statute upheld in Muller be-

granted, 106 S. Ct. 783 (1986); Miller-Wohl v. Commissioner of Labor \& Indus., 692 P.2d 1243 (Mont. 1984), petition for cert. filed, 106 S. Ct. 777 (1985).

51. For insightful analyses of the judiciary's attitudes toward the childbearing capacity of women, see Freedman, Sex Equality, Sex Differences, and the Supreme Court, 92 Yale L.J. 913 (1983); Law, Rethinking Sex and the Constitution, 132 U. Pa. L. Rev. 955 (1984); Scales, Towards a New Feminist Jurisprudence, 56 Ind. L.J. 375 (1981); Taub \& Schneider, supra note 5; Williams, Equality's Riddle, supra note 12.

52. See Williams, Equality's Riddle, supra note 12, at 345-51.

53. 83 U.S. (16 Wall.) 130 (1873).

54. 208 U.S. 412 (1908).

55. 83 U.S. (16 Wall.) at 141 (Bradley, J., concurring).

56. See Lochner v. New York, 198 U.S. 45 (1905) (declaring statute regulating hours of bakers an unconstitutional invasion of substantive due process right to property and its companion freedom to contract).

57. 208 U.S. at 421. 
came a formidable barrier to women's advancement in the workplace. These laws guaranteed that women could not compete with men who were unrestricted by paternalistic protections, and they thus contributed to job segregation and wage depression. ${ }^{58}$

Unfortunately, these pronouncements cannot be dismissed as archaic notions that no judge or employer would dare hold today. The idea of women's unique physical vulnerabilities motivated the Supreme Court, as recently as 1977, to uphold the exclusion of women from the position of guard in an all-male maximum security prison. ${ }^{59}$ Similar views also justify the exclusion of women of childbearing capacity, broadly defined, from certain jobs that are considered hazardous to their reproductive health. ${ }^{60}$ For example, a district court upheld as nondiscriminatory Olin Corporation's policy excluding only fertile women from working in jobs that entailed exposure to certain chemicals capable of causing birth defects. These chemicals, such as lead, can also cause genetic damage to men and their offspring. ${ }^{61}$ Despite the employer's lack of attention to male reproductive harm, the court upheld the women-only policy because it was "instituted for sound medical and humane reasons ... not ... with the intent or purpose to discriminate against females because of their sex ...."62 Although the appellate court rejected the lower court's reasoning as inconsistent with developed title VII law, it permitted the same result-exclusion of fertile women from the highest paying and traditionally male occupied jobs-because of their childbearing capacity. The appellate court

58. For a history of the adverse economic effects on women of protective legislation, see generally J. Baer, Chains of Protection (1978) (recounting judicial response to women's labor legislation from the nineteenth century to the present); A. Kessler-Harris, supra note 17 , at 180-214 (describing protective labor legislation from the Civil War to World War I).

59. Dothard v. Rawlinson, 433 U.S. 321 (1977). Women were restricted to the position of guards in medium and minimum security prisons and were less well paid than guards in all-male maximum security prisons. Although this is not a pregnancy case, the attitudes about the job impact of supposed physical vulnerability are rooted in the same underlying assumptions.

60. See generally Finley, The Exclusion of Fertile Women from the Hazardous Workplace: The Latest Example of Discriminatory Protective Policies, or a Legitimate, Neutral Response to an Emerging Social Problem?, in Proceedings of the New York University Thirty-Eighth Annual National Conference on Labor 16-1 (R. Adelman ed. 1985); Williams, Firing the Woman to Protect the Fetus: The Reconciliation of Fetal Protection with Equal Employment Opportunity Goals under Title VII, 69 Geo. L.J. 641 (1981); Note, Getting Beyond Discrimination: A Regulatory Solution to the Problem of Fetal Hazards in the Workplace, 95 Yale L.J. 577 (1986).

61 . The OSHA lead standards note the reproductive dangers to both men and women and set exposure levels accordingly. See 29 C.F.R. $\S 1910.1025$ (1980). For a description of the variety of reproductive risks posed to men by workplace toxins, see Hatch, Mother, Father, Worker: Men and Women and the Reproduction Risks of Work, in Double Exposure 161 (W. Chavkin ed. 1984).

62. Wright v. Olin Corp., 697 F.2d 1172, 1182-83 (4th Cir. 1982) (recounting district court decision). 
found that this exclusion could be justified on the ground that policies based on concern for fetal health were matters of business necessity for employers despite the fact that the business necessity doctrine under title VII has been limited to factors affecting an employee's ability to perform the job. ${ }^{63}$

The breadth of many exclusionary policies-Olin's applied to any woman between the ages of five and sixty-three who could not prove sterility 64 -reflects what may be called the "perpetual pregnancy myth." 65 Since women's natural role is to bear children, it is assumed that all women want to and will become pregnant, and that this can happen at any time without planning or warning. Consequently, women can be prospectively excluded from jobs, or prospectively protected from certain physical rigors that usually warrant higher pay, without regard to their individual characteristics or intentions. In reality, of course, many women in the workforce are emotionally and mentally capable of planning, and do plan, for such a major event as having a child. ${ }^{66}$

63. Id. at 1189-90. For a complete analysis of the ways in which this decision utilizes paternalistic assumptions and departs from accepted title VII principles, see Finley, supra note 60 , at 16-35. For other examples of exclusionary policies, see, e.g., Oil, Chem. \& Atomic Workers Int'l Union v. American Cyanamid Co., 741 F.2d 444 (D.C. Cir. 1984); Hayes v. Shelby Memorial Hosp., 726 F.2d 1543 (11 th Cir. 1984); Zuniga v. Kleberg County Hosp., 692 F.2d 986 (5th Cir. 1982). Although employers such as Olin say that they must exclude all fertile women in order to protect women who may not yet know they are pregnant, the risk during the first few weeks of pregnancy may not be as great as they fear. First, the view of women as being subject to unknown, unplanned pregnancies is an overgeneralization on the part of employers. Moreover, women who are aware of risks to their health or the health of their offspring may be especially likely to plan for pregnancy, including steps such as requesting a transfer in advance. Second, some teratogenic substances (substances that cause birth defects) do not provide a danger of adverse effects until the state of limb formation, which occurs after most women know they are pregnant. See, e.g., Whorton, Considerations About Reproductive Hazards, in Legal and Ethical Dilemmas in Occupational Health 399, 405 J. Lee \& W. Roman eds. 1982) (embryo most vulnerable to most teratogens in third to eighth week after conception).

64. The Fourth Circuit opinion reports the scope of the policy to encompass these ages, although it is hard to believe that the figure "five" is not a typographical error. 697 F.2d at 1182.

65. See J. Stellman, Women's Work, Women's Health: Myths and Realities 179 (1977); Finley, supra note 60, at 16-19 (developing ramifications of perpetual pregnancy myth in context of the toxic workplace).

66. There are many social factors, such as poverty, low self-esteem, cultural and ethnic attitudes toward birth control, and the desire or need to have something to love, that make it difficult for some women, such as inner city adolescents, to plan for pregnancy. See, e.g., F. Furstenberg, Unplanned Parenthood: The Social Consequences of Teenage Childbearing (1976). The growing social problem of teenage pregnancy, however, does not defeat the observation in the text regarding what employers should assume about women in the workforce, because the women who may, for social reasons, be least able to plan pregnancies are also, due to the same social factors, least likely to be in the workforce. 
b. Unsafe and Unreliable: The Overgeneralizations.-The premise that women's natural role makes them unsafe or unreliable as workers is reflected in policies that deny leaves or benefits on the assumption that women will not return full time or with full commitment to the work force after having children. This assumption also underlies the tendency to call into question a woman's job commitment when she seeks some accommodation between her dual roles. ${ }^{67}$ Neither employers nor judges have been particularly sensitive to the way in which the absence of leaves or adequate benefit coverage may turn the assumption of disengagement into a self-fulfilling prophecy. ${ }^{68}$

The view that pregnant women are incapable of holding certain jobs because of safety factors is used as a justification by the airline industry to explain current practices affecting pregnant flight attendants. This industry traditionally fired its stewardesses as soon as they became pregnant. ${ }^{69}$ Currently, many airlines bar flight attendants from flight duty as soon as they become pregnant. ${ }^{70}$ Mandatory grounding is sometimes accompanied by loss of seniority, ${ }^{71}$ and can affect pay and benefits which depend on in-flight hours logged or credited. ${ }^{72}$ The airlines contend that from the moment of conception, pregnant flight attendants cannot safely perform their duties in an emergency, either because of nausea or lack of agility. ${ }^{73}$ Even though any congruence between such dire emergencies and bouts of morning sickness is likely to be rare, courts have readily accepted these safety justifications. The rarity of the proffered danger, and the gross overgeneralization of the policies, is not perceived, much less discussed. Nor have the courts given much consideration to the relevance of the airlines' long history of discrimination against pregnant women in assessing the validity of current safety justifications. The assumptions that nausea can strike

67. See Brill, supra note 43, at 13 ; Frug, supra note 39 , at $70-71$.

68. The message that runs throughout Maternity Policies, supra note 9 , is that women have to adjust their workforce participation in response to the availability of leave, job protection, and wage replacement. Frug, supra note 39, also explores the ways in which women have been forced out of the full time workforce by the inadequacy of maternity leave and childcare policies.

69. See Levin v. Delta Air Lines, 730 F.2d 994, 996 (5th Cir. 1984) (recounting history of discriminatory practices); Burwell v. Eastern Air Lines, 633 F.2d 361, 376 (4th Cir. 1980) (same).

70. See, e.g., Levin, 730 F.2d at 997-1001; Harriss v. Pan Am. World Airways, 649 F.2d 670 (9th Cir. 1980); Burwell, 633 F.2d 361. Other airlines, however, do not ground pregnant flight attendants. That some airlines permit visibly pregnant attendants to fly casts further doubt on the safety justifications of those who continue to bar pregnant attendants.

71. See, e.g., Burwell, 633 F.2d at 364 .

72. Conversation with $\mathrm{K}$. Stone who has served as an attorney for the flight attendant's union (Septermber 11, 1986).

73. See, e.g., cases cited supra note 69 . The cases do not challenge the safety relatedness of grounding flight attendants in the final trimester. They are concerned only with the earlier stages of pregnancy. 
any pregnant woman at any moment without warning and that pregnant women from the very moment of conception are not sufficiently strong or agile to be of much use to passengers in difficult situations, are so pervasive that they are not questioned by the courts. ${ }^{74}$ The medical bases for these assumptions have received no searching examination from courts. Similarly, the courts failed to scrutinize the airlines' failure to ground other physically susceptible attendants, including those with diabetes, or simply those with the flu or colds or stomach disorders. It has been assumed that pregnant women cannot be responsible for their own particular physical limitations.

The tendency to overgeneralize and to overreact to the supposed frailties of pregnancy can also be seen in the recently demised mandatory maternity leave policies. Under such policies, women were forced to leave their jobs at a certain fixed point in their pregnancy. They were then required to stay away from work for a predetermined period after birth. These dates were set without regard to any individual woman's actual ability or desire to work.

The overgeneralizations that characterize the hazardous chemical exclusion policies, the flight attendant cases, and the mandatory maternity leave policies illustrate the firm hold of the natural role ideology. Women are to be treated as a monolithic block when it comes to policies intended to protect their natural function. If men of medicine had traditionally paid more attention to a woman's perspective on what being pregnant is actually like, how it actually affects women's physical capabilities, and how women can function while pregnant, ${ }^{75}$ the assumption that all pregnant women are equally vulnerable or equally incapable might have collapsed.

The sweeping overgeneralizations supporting these pregnancy policies deny each affected woman the opportunity to make choices about her own life and to realize her own human potential. At the same

74. For example, in Levin, the court acknowledged that medical evidence about the capacities of pregnant women is in conflict, but concluded nonetheless that even though most pregnant flight attendants would never be afflicted with disabling conditions while in the air, the inability to predict in advance which women would be so afflicted justified excluding all pregnant women. The basis of the assumption that conditions such as nausea could never be predicted in advance was never examined by the court. $730 \mathrm{~F} .2 \mathrm{~d}$ at 997-98. Similarly, in Burwell, the court noted the conflicting medical testimony about the frequency of disabilities accompanying pregnancy and the impact of physical exertion during pregnancy. The court also acknowledged that there were no empirical studies concerning the actual performance of pregnant flight attendants during emergencies, partly because such a congruence of circumstances rarely arose. Nonetheless, the court upheld a policy barring all pregnant flight attendants from flight duty after the thirteenth week of pregnancy. $633 \mathrm{~F} .2 \mathrm{~d}$ at $366-67,371$.

75. For an account of the way medical experts have dealt with pregnancy, often in ways that deprived women of a meaningful voice or confidence in their abilities to be attuned to and in control of their bodies, see B. Ehrenreich \& D. English, For Her Own Good: 150 Years of the Experts' Advice to Women (1979); see also supra note 20 and accompanying text (discussing mandatory maternity leave policies). 
time, the ignorance that leads to the tendency to overgeneralize or overstate the risk is reinforced: when women are removed from the workplace as soon as visibly pregnant, employers and male workers are deprived of the opportunity to learn what the capacities or vulnerabilities of pregnant women actually are.

2. Aesthetic and Moral Qualms.-The twin problems of ignorance and failure to consider women's perspective are closely related to another set of values underlying pregnancy policies-aesthetic and moral queasiness triggered by the sight of pregnant women. ${ }^{76}$ These qualms stem from our society's deeply ambivalent attitudes toward female sexuality. Pregnancy is an obvious manifestation of one kind of female sexuality. ${ }^{77}$ Because many of us, especially men, do not understand what it is like to be pregnant and are stirred by conflicting and complicated feelings of envy, fear, and uncertainty about how the condition is actually affecting the woman, the sight of a pregnant woman can arouse either discomfiting protective impulses or disgust. Most of us have an acute feeling that there is something different and special about a pregnant woman and that some of this difference is rooted in biological needs. It is hard to treat her just like any other worker. Consequently, employers have sometimes feared that male workers would be distracted from their duties if they had to work alongside pregnant women. ${ }^{78}$

For some positions, such as airline flight attendants, women have been sought for their sexual attractiveness or availability. Indeed, most airlines refused, until recently forced to by the courts, to hire married women or men as flight attendants. ${ }^{79}$ It does not take much imagination to suppose that the real motivation for these policies was the desire to have sexually attractive and available women to cater to businessmen. ${ }^{80}$ Pregnant women are considered neither sexually attractive nor

76. See Maternity Policies, supra note 9 , at 35 .

77. See, e.g., E. Gamarnikow, The Public and the Private 128 (1983).

78. Maternity Policies, supra note 9 , at 35 .

79. This industry history is recounted in Levin v. Delta Air Lines, 730 F.2d 994, 996 (5th Cir. 1984), and in Burwell v. Eastern Air Lines, 633 F.2d 361, 372, 376 (4th Cir. 1980). In Diaz v. Pan Am. World Airways, 442 F.2d 385 (5th Cir.), cert. denied, 404 U.S. 950 (1971), the court struck down as violative of title VII Pan American's policy of hiring only women for the position of flight attendant. See also Sprogis v. United Air Lines, 444 F.2d 1194 (7th Cir.), cert. denied, 404 U.S. 991 (1971) (policy of hiring only single women, and of dismissing flight attendants as soon as they married).

80. For example, in Diaz, 442 F.2d at 387, Pan American asserted that being female was a bona fide occupational qualification for the job of cabin attendant because the cosmetic value of women created a more pleasant and soothing cabin atmosphere, and customers expressed a strong preference for being catered to by women. The court held that customer preferences based on stereotypes about sex roles could not make sex a bona fide occupational qualification. See also Wilson v. Southwest Airlines, 517 F. Supp. 292 (N.D. Tex. 1981), in which airline sought to justify its policy of hiring only women as flight attendants because they had sex appeal and nurturing qualities upon which they had built a successful marketing image as the "love" airlines. The court held 
sexually available.

For other jobs, such as schoolteachers, women have been subtly expected to appear asexual. School teachers should not be visibly pregnant in the classroom because that might arouse illicit thoughts or embarrassment in the children. In Cleveland Board of Education v. LaFleur, ${ }^{81}$ in which the Supreme Court struck down a mandatory leave policy, the employer specifically referred to these concerns to justify its mandatory maternity leave policy. The Board had selected the employment cut-off date to coincide with the time most women "begin to show," both to save teachers from embarassment at the expected giggles of schoolchildren, and to spare the children from the inappropriate sight of an obviously pregnant woman. ${ }^{82}$ The very fact that schoolchildren or male workers have been insulated from the sight of pregnant women has only helped to reinforce the mystery and embarassment that justified the exclusions.

While proclaiming female sexual activity, pregnancy can simultaneously serve as a denial of sexual attractiveness or availability ${ }^{83}$ The prevalent view in our culture is that to be sexually attractive a woman must be slim and should confine her curves to places other than the belly. A pregnant woman is often thought of as fat and sexually unattractive. It is no coincidence that the airlines, which fired or grounded women when they became pregnant, also had stringent attractiveness qualifications for flight attendants, including weight guidelines.

For those who might assume that the prevalence of particularly unaccommodating policies in female-dominated sectors of the workforce refutes the thesis that male-biased norms are at work, this discussion should suggest that male-oriented values have indeed played a signifcant role in traditionally female jobs. There is often a male expectation that women workers, especially in certain female-dominated job categories, be sexually enticing and available. Moreover, desirable qualities of female sexuality have tended to be defined according to what men find pleasing. This inability to distinguish women as workers from women as sexual creatures has been a fundamental aspect of the subordination of women in the workplace. ${ }^{84}$

that female sex appeal was not a bona fide occupational qualification because the business of the airline was transporting passengers, rather than catering to their sexual desires.

81. 414 U.S. 632 (1974).

82. Id. at 681 n.9.

83. Another reason that pregnancy connotes sexual unavailability is because of its cultural assocation with marriage and fidelity. There are also cultural taboos about engaging in sexual activity while in advanced, visible, stages of pregnancy. Thus, it is no coincidence that the same airlines which refused to hire married women continue to remove women from flight duty when they are pregnant.

84. Catherine MacKinnon's work discusses the ways in which men have defined female sexuality according to their own interests, desires, and perceptions, see MacKinnon, supra note 5, and the ways in which this male power to impose definitions 
3. Pregnancy as Voluntary. - Another related pair of widespread assumptions underlying pregnancy policies is the view that pregnancy is normal and natural for women, and is a voluntary choice that they make. The significance of this assumption is that it has seemed somehow illogical to approach pregnancy as a disability or an illness-it would be a shame to treat something so natural, that women freely choose, as if it were something unfortunate like a workplace injury. In addition, it has seemed somehow unfair for employers to have to pay, under disability or illness policies, for a woman's expected choice to assume their natural role. ${ }^{85}$ Indeed, employers frequently justify their lack of pregnancy coverage by complaining about the cost of covering something that they assumed would, because of its naturalness, occur frequently. ${ }^{86}$ Employers have thus suggested that to give benefits to women who would not come back to the workforce would be unfair to "real" workers. Thus, in the guise of applauding motherhood, women are again penalized for it in the public sphere.

The best evidence of this set of assumptions at work can be found in the Supreme Court's pair of opinions upholding the exclusion of normal pregnancy from employer disability plans-Geduldig v. Aiello ${ }^{87}$ and General Electric Co. v. Gilbert. ${ }^{88}$ The Court stressed that there was nothing arbitrary or invidious about excluding normal pregnancy from disability coverage. By emphasizing the normalcy of pregnancy, coverage for pregnancy and related conditions can be contrasted to the very idea of a disability plan. ${ }^{89}$ The Court, displaying a stubborn obliviousness to the history of pregnancy discrimination and the way it had contributed to the economic and social subordination of women, char-

and expectations of sexual attractiveness and availablity leads to the economic subordination of women, see C. MacKinnon, Sexual Harrassment of Working Women 9-51 (1979).

85. Ann Scales observed, in her analysis of the Supreme Court's pregnancy benefit cases, that "the spectre of paying women to have children is rife in" the Court decisions and congressional deliberations on the Pregnancy Discrimination Act. Scales, supra note 51 , at 387 . 408-09.

86. See Maternity Policies, supra note 9 , at 44-45, 73-74; Scales, supra note 51, at

87. 417 U.S. 484 (1974). Geduldig was brought under the equal protection clause, since it challenged the state of California's exclusion of normal pregnancy related disabilities from its state-administered disability insurance plan.

88. 429 U.S. 125 (1976). Gilbert was a title VII action, since it challenged a private employer's exclusion of disabilities associated with normal pregnancy from its sickness and disability income protection plan.

89. For example, the district court in Gilbert found that pregnancy was usually voluntary, and was not a disease. 375 F. Supp. 367, 377 (E.D. Va. 1974). The Supreme Court used these findings to support its conclusion that because there were no risks (or diseases) from which men were protected but women were not, the exclusion of pregnancy from a disability plan was not sex-based discrimination. The Court also used the lower court's refusal to classify pregnancy as an illness as a basis for rejecting the contention that the exclusion of pregnancy from a sickness and disability plan was a pretext for sex discrimination. 429 U.S. at 135. 
acterized the issue as whether an employer had to provide an all-inclusive benefit plan and thereby compromise the fiscal solvency of its program "in order to finance the payment of benefits [for] . . . normal pregnancy and delivery." 90

The separate spheres ideology can also be seen in this focus on voluntariness and choice. Since it is assumed that women's natural place in the family world is incompatible with their holding a place in the work world, women are seen as "choosing" to assume their ordained place in the private sphere when they "choose" to become pregnant. The view that pregnancy is a truly voluntary choice displays insensitivity to the way in which barriers to women's participation in the work world have made them economically dependent on men. This economic dependence has meant that their assumption of the roles of wife and mother is more often a matter of necessity than free choice. ${ }^{91}$

The voluntary choice assumption, when used as an argument against pregnancy coverage in the workplace, misses the point for two reasons. First, it denigrates the importance of pregnancy and overlooks the way in which it affects both men and women..$^{92}$ Second, simply because pregnancy is often voluntary hardly means it has no connection to the workplace. The fact that pregnancy is essential, and the way it affects men and women, affirms its connection to the public world of workplace production. ${ }^{93}$ At one level, we must procreate to provide more workers, and we must work to support those we have procre-

90. Geduldig, 417 U.S. at 494.

91. For economic analyses of the constraints on women's choice of roles, see A. Jaggar, Feminist Politics and Human Nature 133-43 (1983); Ferguson \& Folbre, The Unhappy Marriage of Patriarchy and Capitalism, in Women and Revolution 313, 319-20 (L. Sargent ed. 1981); Lange, Reproduction in Democratic Theory, in 2 Contemporary Issues in Political Philosophy 140 (W. Shea \& J. King-Farlow eds. 1976). For explorations of the effect of the creation and glorification of the institution of motherhood on women's self-conceptions and choice of roles, see A. Dally, Inventing Motherhood: The Consequences of an Ideal (1982); A. Rich, Of Woman Born: Motherhood as Experience and Institution (1976). The psychologist Nancy Chodorow provides yet another perspective: the cultural and psychological conditioning that is perpetuated by the primacy of women as childrearers. N. Chodorow, The Reproduction of Mothering (1978).

92. Although reproductive technology now makes it possible for women to have children without the involvement of a man, it is still by far the predominant pattern for a man to be involved. When I refer in this Article to the mutual concern of men and women in pregnancy, however, I do not intend to disparage or ignore lesbian mothers or the many women who have children or raise them without the presence of a man. In these situations the point still remains that there will usually be other human beings affected by the pregnancy, whether a lover, or extended family members, who help raise the child.

93. The workplace routinely accommodates other basic human needs. For example, vacation time is a basic expectation, even though the need for leisure is, at first glance, antithetical to work. The very fact that leisure is an essential part of remaining a productive and healthy person means that the workplace must take this need into account. Similarly, since our family lives are such a crucial feature of who we are and how we function, they too are connected to the work aspect of our lives. 
ated. ${ }^{94}$ At another level, when a pregnant woman loses her job or pay or benefit coverage, a man, or another person with whom she has a relationship, also suffers economically and may have to assume extra work burdens to make up the gap. These extra burdens can affect his health, perfomance, and productivity. If recognition of the interrelation between pregnancy, men, women, and work had been the starting point for the Supreme Court's analysis, any sense that it was unfair to employers or other workers to pay for a voluntary and normal condition would have dissolved into the view that it is just and necessary for employers fully to cover maternity because parenthood is essential to employees of both sexes, affects the work lives of both, and thus, is also of concern to employers.

4. Pregnancy as a Special Women's Problem.-Related to the voluntary choice perspective is the assumption that workplace accommodation of maternity is a special women's problem, rather than an issue that affects both men and women. After all, since it is women who get pregnant and who still bear most of the responsibility for rearing children, it is women who are most concerned about whether an employer has adequate maternity leave, offers flexible working arrangements, or subsidizes childcare ${ }^{95}$ While this may be a partially true picture of present social reality, it is inadequate. Men are affected when women with whom they are affiliated cannot get paid leave or cannot maintain sufficient health insurance, or when they must go back to work before they have fully regained their energy, or before the child is old enough to be accepted into most child-care programs. Men, too, are affected in the work world by the sleepless nights that are common during a baby's early months of life. The persistence of the assumption that this is a woman's issue, and the fact that few men make demands for parenting leave or childcare, highlights the entrenchment of male norms and the ideology of separate spheres. Until the assumption of male norms is overcome through constant challenge and the changing composition of the workforce, childbearing and childrearing are likely to remain women's issues.

The jurisprudential significance of this assumption is twofold. First, in our male-dominated world, labeling something as a women's issue has a pejorative and marginalizing effect. It makes it hard for judges, legislators, or employers, most of whom still are men, to take the issue seriously or to understand its ramifications. If the majority of

94. Socialist feminists have offered a cogent critique of traditional Marxist thought for the way in which it attempts to disassociate reproduction from production-or the public from the private. See A. Jaggar, supra note 91, at 134-37, 143-48, 155-62.

95. This attitude might explain why unions, which are usually led by men and have operated with greater force within male-dominated industries, traditionally have not made maternity leave and childcare assistance important issues on their agendas. See, e.g., Maternity Policies, supra note 9, at 71, 153-54. Recently, however, some unions have been pushing for maternity leave and have supported parental leave legislation in Congress. See, e.g., Wall St. J., June 6, 1986, at 24, col. 5. 
the Supreme Court had appreciated the seriousness or the historical context of the pregnancy benefit issue, it is unlikely that they would have characterized the issue in Geduldig and Gilbert as one of preserving the fiscal integrity of an employer's voluntary insurance scheme. The second legal implication is that the words "women's issue" conjure up the antidiscrimination framework for analysis, rather than a substantive rights framework. At the same time, the notion that something is of special concern to women, and not a women's and men's issue, tends to suggest the lurking presence of differences between men and women that might allow a policy to survive the scrutiny of antidiscrimination analysis on the ground that the policy does not involve "similarly situated" individuals.

5. Pregnancy as Unique.-Permeating and sustaining each of these assumptions is the view that pregnancy is unique-that it affects only women and it is like no other human condition in its immediate physical effects, significance, and consequences. This fundamental assumption of uniqueness cannot easily be disputed, and it is not likely soon to wither away ${ }^{96}$ Many women and men of a wide variety of political outlooks wish not to dispute pregnancy's uniqueness, but to celebrate it. ${ }^{97}$ For example, when I contemplate Richard Wasserstrom's perceptive and provocative article on racial and sexual equality in which he proposes an ideal world where a person's sex will make about as much difference as eye color, ${ }^{98}$ my reaction is disquiet and sadness. I sense that we will have lost something very fundamentally human in such a world of no "real" differences. My sense of loss stems from a feeling that $I$ as a woman want to be able to revel in the joy and virtually mystical specialness of having a baby. What I do not want is to be punished for this wonderful gift at the same time. My feeling that something will be missing in this ideal androgynous world also comes from a fear that

96. Shulamith Firestone, in her book The Dialectic of Sex (1970), envisions a world in which advanced medical technology will make it possible for men to be equally involved in bearing children, and gender distinctions associated with childbearing will wither away. She sees this separation of reproduction from the female body as a necessary condition for women's freedom.

97. The right-to-life political coalition, whose members are often quite conservative, celebrates the specialness of pregnancy. See, e.g., K. Luker, Abortion and the Politics of Motherhood 138, 145, 151-54, 159-63 (1984) (describing world views of rightto-life activists). The liberal feminist theorist Elizabeth Wolgast also proclaims the uniqueness of pregnancy and the value of traditionally female qualities. E. Wolgast, Equality and the Rights of Women (1980). The radical French feminists also take a celebratory attitude towards the female "essence," which includes the joy and the power of the ability to have children. These writers recognize that the ability to become pregnant holds the potential for great power if male-dominated value structures are altered to be more inclusive of the entirety of human experience. See, e.g., J. Féral, The Powers of Difference, in The Future of Difference 88 (H. Eisenstein \& A. Jardine eds. 1985).

98. Wasserstrom, Racism, Sexism, and Preferential Treatment: An Approach to the Topics, 24 UCLA L. Rev. 581 (1977). My reaction to Professor Wasserstrom's proposal is colored by the fact that, as a blue-eyed blond, I know that these features have made a difference in the way I have been perceived and judged by others. 
it rests on a vision of equality that says we can all be equal if we just strip away all our differences. Life in such a world would be boring, impoverished, and unenriching. It would offer little prospect of having our horizons and experiences expanded by exposure to the wonderful and infinite variety of human differences. The problem is not the uniqueness of something like pregnancy, but the view that our legal system has adopted towards "special" human qualities, particularly qualities that are special because they are inherently female in the sense that they cannot be experienced by a male.

The assumption of uniqueness is problematic for women because antidiscrimination doctrine treats truly unique situations differently and far too often, worse. The penalization of women because of their childbearing capacity is thereby legitimized. For example, the Supreme Court has often pointed to the maternal functions and role of women as a "real," or natural, sex difference which justifies the maintenance of barriers to integrating women into the public sphere. ${ }^{99}$ In both Geduldig and Gilbert, the Court majority relied on the uniqueness of pregnancy to support its exclusion from disability plans. Its uniqueness, and its uniqueness to women, meant that there was no discrimination. "There is no risk from which men are protected and women are not. Likewise, there is no risk from which women are protected and men are not." 100 The Court then demonstrated the risks of viewing pregnancy as something that only affects women when it brought the uniqueness assumption to its apparently obvious denouement: "The lack of identity between the excluded disability and gender as such under this insurance program becomes clear upon the most cursory analysis. The program divides potential recipients into two groupspregnant women and nonpregnant persons. While the first group is exclusively female, the second includes members of both sexes." 101 In other words, because pregnancy is unique to women, and nonpregnancy is not, there is no gender-based connection between pregnancy and women.

The point of this recitation of Geduldig and Gilbert is not simply to show that five male members of the Supreme Court were blind in a way that even Congress was not. ${ }^{102}$ Rather, the point is that the assumption of uniqueness, when placed within the framework of antidiscrimination

99. For an analysis of the Supreme Court's use of the category of natural, or "real" sex differences, see Freedman, supra note 51.

100. Geduldig, 417 U.S. at 496-97. For perceptive analyses of the uniqueness view in these cases, see Freedman, supra note 51, Scales, supra note 51, and Williams, The Equality Crisis: Some Reflections on Culture, Courts, and Feminism, 7 Women's Rights L. Rptr. 175 (1982) [hereinafter Williams, Equality's Crisis].

101. Geduldig, 417 U.S. at $496-97$ n.20.

102. Congress overruled Gilbert in the Pregnancy Discrimination Act, and explicitly declared what the Supreme Court majority would not recognize: pregnancy is sexlinked, thus, discrimination on the basis of pregnancy is sex-based discrimination. Pub. L. No. 95-555, § 1, 92 Stat. 2076 (1978) (codified at 42 U.S.C. § 2000e(k) (1982)). 
doctrine, promotes blindness. By blindness I mean an unwillingness, verging on an inability, to question the validity of the assumptions underlying maternity policies. This sort of blindness promotes a refusal to question the structures that are built upon the underlying assumptions. This failure to see or to question then reinforces the apparent naturalness of it all. ${ }^{103}$

The Pregnancy Discrimination Act (PDA) rejected the Supreme Court's use of the uniqueness assumption in Gilbert. ${ }^{104}$ The proponents of the Act felt that the wisest strategy was to adopt the similarities approach of traditional antidiscrimination theory to assail the way the uniqueness assumption had been used against women. The similarities approach views the problem in Gilbert as a failure to see that, despite its normalcy and frequent voluntariness, pregnancy has effects like disability. Thus, the PDA declares that pregnancy shall be treated in the same manner as other disabilities that also make people unable to work at particular moments. ${ }^{105}$

But, just because Congress has declared that pregnancy shall no longer be viewed as unique with regard to an individual's physical capability to perform a job, the uniqueness assumption has not been swept out of our consciousnesses. It is too fundamental to our whole conception of sex roles to disappear so easily. The prevalence of this assumption makes the application of equality analysis problematic, because, as pointed out in the next part of this Article, that analysis sees "uniqueness," or lack of similarity, in a pejorative light. Moreover, Congress' declaration that there are workplace situations in which pregnancy is not unique has not dominated the field upon which the uniqueness assumption can operate. What about after the woman has given birth, when her and her baby's emotional and health needs may pull her away from the workplace even though she is probably able to work in the limited physical sense of most disability policies? What about the employer who fails to offer job protection for any disabilities? Isn't this a virtual seal of doom for any woman who does bear a child, given that

103. This has been true in gender discrimination cases in contexts other than pregnancy. In many of its gender discrimination decisions, such as Rostker v. Goldberg, 453 U.S. 57 (1981); Personnel Adm'r v. Feeney, 442 U.S. 256 (1979); Califano v. Webster, 430 U.S. 313 (1977); Schlesinger v. Ballard, 419 U.S. 498 (1975); and Kahn v. Shevin, 416 U.S. 351 (1974), the Court has accepted the existence of socially constructed differences as justifying further discriminatory differential treatment, and has demonstrated apparent blindness to the fact that the problem is the underlying socially constructed differential conditions of men and women. See Wildman, The Legitimation of Sex Discrimination: A Critical Response to Supreme Court Jurisprudence, 63 Or. L. Rev. 265, 282, 285 (1984).

104. See Williams, Equality's Riddle, supra note 12; Note, Employment Equality Under the Pregnancy Discrimination Act of 1978, 94 Yale L.J. 929 (1985).

105. The text provides that "women affected by pregnancy, childbirth, or related medical conditions shall be treated the same for all employment-related purposes, including receipt of benefits under fringe benefit programs, as other persons not so affected but similar in their ability or inability to work." 42 U.S.C. $\$ 2000 \mathrm{e}(\mathrm{k})(1984)$. 
pregnancy is unique to women in the way that the flu, broken limbs, cancers, and heart ailments are not?

Questions such as these prompted some states to enact laws requiring provision of reasonable maternity leave regardless of an employer's other leave policies. ${ }^{106}$ These laws have set off the special treatment/equal treatment debate. In many respects, this debate is an inevitable consequence of the pervasiveness of the uniqueness assumption. Because this assumption is so powerful, and has been used so often against women in the past, we must ask ourselves whether the only way to overcome it is to deny it constantly, even when women do have needs that men do not have and thus can also be hurt by the lack of the assumption. Or, is it better to recognize that the assumption is fundamental and often true and can be used to help women overcome the harms of a workplace that has traditionally displayed little sensitivity to women's needs?

\section{The Equal Treatment/Special Treatment Debate and a Critique of Equality ANalysis}

The ideal of equality - that similarly situated individuals should be treated alike-is basic to our political and legal system. ${ }^{107}$ By appealing to equality and the doctrine of antidiscrimination, women have been able to make great strides toward the goal of improving their social status and power. Equality theory has been particularly useful for gaining access to traditionally male prerogatives within the public sphere. ${ }^{108}$ It works well and should continue to be the guide when the goal is assimilation of women into male institutions. Assimilation, however, too often means the creation of "a world in which persons of both genders are encouraged to act as men currently do and in which current 'female behavior' will gradually wither away."'109 This conception of the ideal world that underlies equality jurisprudence is precisely why it is limited and problematic in the pregnancy context, and in other gender contexts where women have qualities or perspectives that can

106. See supra note 49 and accompanying text.

107. In critiquing the legal doctrine of antidiscrimination that flows from this ideal, I do not mean to suggest that it should be dispensed with in all situations. My point, rather, is that traditional equality doctrine is limited, and in many respects is designed to perpetuate the status quo and thereby avoid meaningful social change. The effort to eliminate the pejorative and subordinating effects of gender hierarchy provides an illuminating example of its limitations.

108. These types of sex discrimination cases bear a close resemblence to racial civil rights cases, which primarily sought to achieve access for minorities to previously all white institutional preserves and prerogatives. These cases, which appeal to the value of individualist achievement, provided the doctrinal model of equality resorted to by women to claim their right of participation in the public sphere. See Karst, Woman's Constitution, 1984 Duke L.J. 447, 470. (1981)

109. Note, Toward a Redefinition of Sexual Equality, 95 Harv. L. Rev. 487, 487-88 
enhance the male sphere and should not be dispensed with. ${ }^{110}$ Pregnancy is essential to the human race, and it is an area in which women cannot and should not act like men. It is "female behavior" that is not going to gradually wither away. Where gender distinctions arise from biological facts, or where they have culturally existed, women are not similarly situated to men. Existing institutional structures therefore have distinct implications for women and men. Given this reality, equality doctrine is not going to advance women very far. The doctrine inherently assumes that the goal is assimilation to an existing standard without questioning the desirability of that standard and thus it limits the debate to what policies will best achieve the assimilation.

\section{A. The Special Treatment/Equal Treatment Debate Summarized}

The special treatment/equal treatment debate reflects the limiting focus of equality analysis. Each side agrees that women should have the right not to be penalized as workers for being childbearers and for having principal childrearing responsibility. ${ }^{111}$ The split comes over how

110. While my analysis in this Article focuses on the limitations of equality theory for dealing with pregnancy and childrearing, the analysis is equally applicable to other currently troublesome gender issues such as comparable worth and sexual harassment. Comparable worth has been particularly resistant to fitting comfortably within an equality framework because in female-dominated job categories, there are no men to be used for comparison purposes. The problem goes deeper than a comparison-focused analysis can possibly see. One of the reasons why in certain jobs there is a dearth of men to be used in an equal pay type of comparison is that men have historically had far more employment options than women. Male-dominated jobs have offered higher pay due to assumptions about the male's role as family breadwinner and due to the higher value our society has placed on masculine qualities and skills.

Efforts to fit sexual harassment into the framework of antidiscrimination doctrine have led courts to pose questions that are utterly beside the point, such as whether harrassment by a bisexual supervisor would still violate title VII. See, e.g., Vinson v. Taylor, 760 F.2d 1330, 1333 n.7 (D.C. Cir. 1985) (Bork, J., dissenting from denial of rehearing en banc), aff'd and remanded sub nom. Meritor Sav. Bank, FSB v. Vinson, 106 S. Ct. 2399 (1986); Barnes v. Costle, 561 F.2d 983, 990 n.55 (D.C. Cir. 1977). The comparison-oriented approach misses the point of sexual harassment-it is something that has happened to women because of their sexual and economic subordination to men and because of the way in which men have used their power over women to objectify them and control their sexuality. See C. MacKinnon, supra note 84 .

Each of these issues might be approached more fruitfully under the expanded conceptions of human needs, interconnectedness, and responsibilities suggested in this Article. Then, we might understand the social constructs that have contributed to women's job segregation and wage depression, and the way in which this economic subordination of women adversely affects us all. Similarly, we might arrive at a more satisfactory appreciation of the way in which the loss of human dignity in the workplace that accompanies sexual harassment affects the business enterprise and all workers, because it is one manifestation of the dehumanizing attitudes that pervade many workplaces. These richer conceptions of the problems teach us that rather than simply being matters of discrimination, they are instances of the failure of society and our legal system to address many basic human needs.

111. The preeminent academic spokeswoman for the equal treatment view is Professor Wendy Williams. See Williams, Equality's Crisis, supra note 100; Williams, 
to realize that right and about what constitutes a penalty: is it not being treated as men are, or is it not being treated as a woman? The answer, however, is that it can be both, depending on the sitution, and what one considers male-like or "equal" treatment, and on what form the femalelike or "special" treatment will take. 112

Essentially, the debate is between two strands of traditional liberal equality theory-formal versus substantive equality, or equal opportunity versus equal outcomes. By formal equality I mean the doctrinal model that would treat likes alike. The rule requires us first, to identify relevant similarities and then, to treat two similar individuals the same. By substantive equality I mean the doctrinal model which acknowledges that parceling out goods such as workplace benefits according to egalitarian distributive principles may not result in people's positions actually coming out equal in the end. To make the competition equal, people may need varying underlying substantive entitlements. Individual needs and positions may have to be taken into account in any particular situation in order to achieve equality of outcome. ${ }^{113}$

Equality's Riddle, supra note 12. The special treatment, or special rights, view is set forth in E. Wolgast, Equality and the Rights of Women (1980) (proposes what has become known as bivalent approach, under which a variety of differences between the sexes, both biological and socially constructed, are taken into account under a regime of special rights); Krieger \& Cooney, supra note 12; Scales, supra note 51, at 435 (pregnancy and breastfeeding are true biological gender differences which must be incorporated into equality jurisprudence to make it more encompassing of female experience; the thrust of her position is to alter our conceptions of equality rather than to work within the given framework of equality doctrine); Note, supra note 104 . One could also include aspects of Sylvia Law's analysis in her article Rethinking Sex and the Constitution, 132 U. Pa. L. Rev. 955 (1984), as aligning her with the special treatment position. She acknowledges that pregnancy is a true biological gender difference, and a special and unique experience, that requires a legal approach other than straightforward equal treatment. She proposes a standard under which biologically sex-based classifications are permissible if they do not contribute to perpetuating the oppression of women or culturally imposed sex role constraints. Id. at 1007-08. Professor Herma Kay offers a compromise position that draws on strands of both equal treatment analysis and special treatment insights. She uses the framework of equality of opportunity to argue that maternity leave laws can be supported under an "episodic analysis" that focuses on the temporary, episodic, and different consequences of reproductive behavior engaged in by men and women. In order to maintain equality of opportunity, and to remove for women a conflict that does not exist for men between the right to engage in reproductive behavior and work opportunities, pregnancy must be accommodated by the workplace. Kay, Equality and Difference: The Case of Pregnancy, 1 Berkeley Women's L.J. 1, 21-35 (1985). While the views of each commentator differ somewhat, and no single writer espouses every feature of the position as described in the text, the summary of the debate in the text reflects the general tendencies of each position.

112. See Olsen, Statutory Rape: A Feminist Critique of Rights Analysis, 63 Tex. L. Rev. 387, 398-400 (1984).

113. The tension between formal equality and substantive equality is analogous to the tension between rules and standards, or the general and the particular. See Kennedy, Form and Substance in Private Law Adjudication, 89 Harv. L. Rev. 1685 (1976). Formal equality is the embodiment of a general rule, but as with such rules, if too rigidly applied, the outcome may actually undercut the goal that motivated the rule. 
In many respects, each side of the debate accepts the notion that the public world of the workplace and the private world of the home are separate spheres. They both see the problem as the relegation of women to the private sphere through barriers erected in the public sphere. The goal, then, is to make women more equal in the workplace sphere. ${ }^{114}$ Both agree that one way to achieve this goal is to support legislative initiatives to make parenting leaves available to men and women. ${ }^{115}$

Equal treatment proponents emphasize that a woman's "specialness"-her childbearing function-historically has led to paternalistic protective legislation which has forced women back into the home. They argue that women cannot have it both ways by asserting that they should be treated just like men in some situations yet claiming the right to be treated better than men in others. ${ }^{116}$ They reject the notion that pregnancy "naturally makes women unequal," (i.e. unlike men) and contend instead that "pregnancy can or should be visualized as one human experience which in many contexts, most notably the workplace, creates needs and problems similar to those arising from causes other than pregnancy, and which can be handled adequately on the same basis as are other physical conditions of employees." 117 The focus is not on whether pregnancy itself is just the same as other conditions, but on the effects of pregnancy on a worker. These effects can be the same as the effects of other conditions. According to this view, the flaw in the Supreme Court's analysis in Geduldig and Gilbert was its failure to recognize the basic similarities between the effects of pregnancy and other disabling conditions. Consequently, the language of the Pregnancy Discrimination Act, which was promoted by equal treatment proponents, declares that "women affected by pregnancy, childbirth or re-

Thus, there exist particular responses, or equitable standards, which tell us to be flexible in dealing with situations to make the outcome responsive to the general goal. But with this approach we sacrifice the certainty of rules and risk subjecting people to the value judgments of others. See id. at 1711. Kennedy's insight is that there is no determinate, coherent way to choose between the approach of rules or the approach of standards, between the general and the particular, between formal equality or substantive equality. Inevitably, the choice depends on our sets of values and visions of society. Id. This insight is central to my critique of equality analysis. There is no way, within the doctrinal framework itself, to tell us when we should adopt the approach of formal equality, and when a substantive equality approach is called for. Instead, we must appeal to deeply political conceptions of what values and type of society we wish to foster. The application of equality analysis and the argument between its two strands masks this level of choice.

114. Both equal treatment and special treatment proponents have acknowledged the structural inequities facing women, and both support legislative initiatives designed to start changing workplace benefits and expectations. See, e.g., The Parental and Medical Leave Act of 1986, H.R. 4300, 99th Cong., 2d Sess. (1986), described infra note 121.

115. See, e.g., Scales, supra note 51, at 444; Taub, supra note 40.

116. Williams, Equality's Crisis, supra note 100, at 196.

117. Williams, Equality's Riddle, supra note 12, at 326. 
lated medical conditions shall be treated the same for all employmentrelated purposes ... as other persons not so affected but similar in their ability or inability to work ...."118

This approach of comparing women to men is defended as preferable because it highlights commonalities in human experiences. ${ }^{119}$ In de-emphasizing the uniqueness of pregnancy, the assumption that pregnancy is just a woman's problem can be overcome. The formal equality model of treating likes alike is also justified as the more objective and value-neutral approach. Thus, it is argued, it poses less danger of judges or employers letting their biases and stereotypes about women guide their decisions. ${ }^{120}$

When employers have inadequate sickness and disability policies, equal treatment proponents contend that women should be just as vulnerable as male workers to job loss. After all, the individualized matching approach requires that pregnant workers be treated neither better nor worse than other "similarly situated" workers. The proper response to inadequate leave policies, in the view of equal treatment proponents, is to fight laws that require only maternity leave, and to lobby for laws that extend adequate illness, disability, and parenting leaves to all workers. ${ }^{121}$

On the "special treatment" side of the debate are those who would treat pregnancy in the workplace as something warranting its own specially tailored policies apart from sickness and disability plans. Special treatment advocates consequently support, as legitimate under title VII, state laws that require employers to provide maternity leave to those who want or need it. ${ }^{122}$ Those who hold this view contend that, given the deep and often unconscious way in which assumptions about pregnancy are so central to our accepted system of gender hierarchy, it is unlikely that a majority of the Supreme Court and the American public will ever view pregnancy as being the same as other conditions,

118. 42 U.S.C. $\S 2000 \mathrm{e}(\mathrm{k})$ (1982).

119. Williams, Equality's Riddle, supra note 12, at 326 .

120. See Krieger \& Cooney, supra note 12, at 543 n.92.

121. See, e.g., Williams, Equality's Riddle, supra note 12, at 377-79. Examples of legislative initiatives supported by both equal treatment and special treatment proponents are: The Parental and Medical Leave Act, H.R. 4300, 99th Cong., 2d Sess. (1986), which would require all employers to provide a minimum of 26 weeks leave to all employees temporarily unable to work because of nonoccupational short-term disability, and would require employers to allow at least 18 weeks of parental leave within a two year period for workers of both sexes in cases of birth, adoption, or serious illness of a child; California Assembly Bill 613 (1985) (unlawful employment practice for any employer to refuse to grant employee's reasonable request for childrearing leave with job security and benefit retention); Massachusetts H.R. Bill 1314 (1985) (12 week parenting leave for birth or adoption with job security and benefit retention). The bills are discussed in Taub, supra note 40, at 402 n.98.

122. Special treatment advocates, therefore, take issue with the challenge to these laws as being in conflict with and preempted by title VII. See infra note 244 . 
either in its significance or its effects. ${ }^{123}$ Many special treatment proponents assert that pregnancy is indeed distinct from any other human condition, and that it is neither necessary, desirable, nor possible to eliminate this biologically rooted sex difference. ${ }^{124}$ Consequently, according to special treatment advocates, we need two kinds of rights: equal rights and special rights. ${ }^{125}$ Special rights are rights based on human differences, taking them into account so that the ultimate outcome between different individuals can be the same. ${ }^{126}$ Those who support special treatment for pregnant women insist that a so-called "neutral" policy, or one that assumes that no group or individual is starting out with special needs or special disadvantages, can, in fact, have differential group effects. Thus, the special treatment argument often relies on the disparate impact strand of antidiscrimination theory. ${ }^{127}$ It also draws from group-based, rather than individualized, models of antidiscrimination theory. Since women as a group have traditionally been discriminated against in the workplace because of their childbearing capacity, positive action in the form of special rights that affirmatively take childbearing into account is necessary to break down the disparities. ${ }^{128}$ A no-leave policy, or a policy that provides so little time off that virtually any pregnant woman will require more than she is entitled to and will thus lose her job because of her pregnancy, has a negative, disparate effect on women as a group. ${ }^{129}$

Special treatment proponents are concerned because the equal treatment model can do nothing positive for women in a workplace that offers inadequate leave policies; it is only as good as the male model with which it can be compared. The fundamental objection to the equal treatment approach is that it inevitably accepts the male norms of the workplace. Special treatment advocates point out that the aversion displayed by equal treatment proponents to talking about pregnancy as unique, and their consequent insistence that women really are just like

123. See, e.g., Krieger \& Cooney, supra note 12, at 541-42 (arguing that the distinctions are likely to leap out with much greater vigor than the similarities).

124. See, e.g., E. Wolgast, supra note 111, at 34; Law, supra note 111; Scales, supra note 51 , at 435 (arguing that since pregnancy and breastfeeding are biologically unique to women they should be dealt with accordingly).

125. E. Wolgast, supra note 111 , at 42.

126. The classic example of a special right is the requirement that buildings be equipped with wheelchair ramps so that both those who can walk and those who cannot, can realize their equal right to have access to public buildings. Id. at 51 .

127. See, e.g., Krieger \& Cooney, supra note 12, at 552, 559; Note, supra note 104, at 951. Equal treatment proponents also state that the disparate impact theory is still available to challenge pregnancy discrimination, despite the parity of treatment language of the Pregnancy Discrimination Act. However, they argue that the import of disparate effects analysis should be to extend greater leave time to everyone, rather than to create a sex based classification resting on arguments of different needs. See, e.g., Williams, Equality's Riddle, supra note 12, at 368, 371, 372-74.

128. See Krieger \& Cooney, supra note 12, at 559-60.

129. See, e.g., Abraham v. Graphic Arts Int'l Union, 660 F.2d 811 (D.C. Cir. 1981). 
men, are rooted in an acknowledgement that male is the standard against which we all should be measured. Uniqueness is a trap for women only under an analysis that assumes maleness is the norm. ${ }^{130}$ The way out of the trap, according to special treatment proponents, is to challenge the male standard by insisting on the incorporation of women into the workplace with due regard for their special capacities and needs. ${ }^{131}$

Special treatment advocates insist that it is acceptable to move incrementally toward the goal of equality in the workplace. ${ }^{132}$ They think it is foolhardy to fight against legislation that women badly need in order to accommodate childbearing and working, just because the vision of an ideal society compels us to recognize that men and nonpregnant women also need certain workplace protections that they currently do not have. ${ }^{133}$ Those who urge equal treatment warn that the incremental approach was previously used against women during the era of protective legislation, and that we must therefore work to achieve the entire ideal set of legal protections for men and women at the same time. ${ }^{134}$

There is an insoluble quality to this debate, reminiscent of many means-ends disputes. The conundrum in which feminists have found themselves is attributable to the limitations and flaws inherent in the doctrinal tradition that we have been given for attempting to "solve" pressing social problems that emerge out of the fact that we are not a perfectly homogeneous society of similarly situated equals. Both sides of the debate appeal to aspects of the doctrinal framework of equality analysis, yet that very framework provides no objectively principled, apolitical basis for making a general choice between the sometimes competing visions of equality of opportunity and equality of outcome.

\section{B. The Special Treatment/Equal Treatment Debate as a Device for Critiquing Equality Analysis}

The limitations of equality analysis as a transformative device for challenging the economic and social subordination of women and attendant limitations on male roles stem from its inability to come to terms in any acceptable, unproblematic manner with the reality of human variety. We are all different, and distinctions of gender are one type of difference that is unlikely ever to disappear. ${ }^{135}$

130. Scales, supra note 51 , at 435 .

131. Id. at 435-36.

132. See, e.g., Krieger \& Cooney, supra note 12, at 569-72.

133. Id.

134. See, e.g., Williams, Equality's Riddle, supra note 12, at 380.

135. As Carol Gilligan has pointed out, "Gender is not exactly like social class. It is not simply a matter of dominance and subordination. There is no way to envision gender disappearing as one envisions, in utopian visions of society, class disappearing or race becoming a difference that makes no difference. The fact that gender is a difference 
1. The Indeterminacy of Equality Analysis. - The first problem with the analysis of traditional equality theory is its indeterminancy-the theory of equality and the legal analysis that implements the theory cannot tell us how to define or identify what is a relevant difference and what is a relevant similarity in any given situation. Equality analysis, along with much of our system of legal reasoning, rests on a process of classifying by analogy. We are taught that to arrive at the right answer we must divide things into groups of "similars," and then we must treat everything within each group "similarly." But who is to say what is a difference or similarity, in the abstract or in the particular? Every person, thing, or condition will always have some qualities that are similar, and some that are different from everything else, even when there is agreement on the category of classification. ${ }^{136}$

For example, the equal treatment proponents are correct when they point out that pregnancy is similar to other conditions in its effect on people's ability or inability to work. But how similar? Pregnancy may require lengthier leave times, and leave may be needed for unique reasons different from other noncatastrophic physical happenings. Thus, special treatment proponents and the Supreme Court majority are, to a degree, correct when they point out that pregnancy is unique. ${ }^{137}$ So, the question that currently, and historically, has so torn

that one cannot envision disappearing is why it makes so many people so angry. It does not fit their schemes of analysis. It is always a thorn in their side." Feminist Discourse, Moral Values, and the Law-A Conversation, 34 Buffalo L. Rev. 11, 76 (1985) (remarks of Carol Gilligan) [hereinafter Feminist Discourse]. Although much of the social significance of gender might disappear in a society restructured to value differences and to be more inclusive of the perspectives and experiences of both genders, as long as there are differential reproductive roles and corresponding predominant patterns of sexual attraction, gender is likely to remain significant.

136. Arthur Leff made this point elegantly in his Legal Dictionary in defining "analogy":

First, it is a fundamental tenet of most systems of justice that identical things be treated identically .... Second, there is no such thing as an identical thing; everything is what it is and not something else. Hence a large part of doing justice consists of trying to treat "similar" things, i.e., things "essentially," or "really" identical the same, i.e., in analogizing one thing to another such that they should be treated as if they were "the same." But what "counts" in the way of similarity or difference? There is always some similarity and some difference. ... When is something so like something else that it should be treated the same, or so unlike that it should not. The key answer is that there is no simple "logical" or "linguistic" answer, no general set of classificatory criteria for making these decisions.

Leff, Legal Dictionary: A Fragment, 94 Yale L.J. 1855, 2016 (1985) (emphasis in original).

This is a problem with all classification and categorization systems-they always distort by assimilating into categories. To escape this dilemma is one of the reasons feminist methodology urges contextualization.

137. The error committed by the Court in Geduldig v. Aiello, 417 U.S. 484 (1974), and General Elec. Co. v. Gilbert, 429 U.S. 125 (1976), was its willingness to ignore the fact that pregnancy is linked with gender, and thus that pregnancy classifications are 
feminists concerns the legal implications of this simultaneous condition of being alike, yet not alike. ${ }^{138}$

Equality analysis simply cannot provide the answer. Only basic political and moral judgments about ultimate social aims can suggest a basis for choosing among possible similarities and dissimilarities. Even when the discourse moves to this value-laden level, it is not possible to guarantee completely satisfactory solutions free of perverse effects that can undermine whatever ultimate goal is at stake. These perverse effects are intrinsic to being both the same and different simultaneously, because as women choose to focus on certain similarities that we think will reduce gender hierarchy, the nagging differences will not disappear from view.

The equal treatment-special treatment debate illustrates this tension between sameness and difference. Undeniably, the equal treatment view embodied in the Pregnancy Discrimination Act has accomplished a great deal for pregnant workers, because the problem too often had been that employers were not treating women workers as well as men workers. The Act served as an impetus for numerous employers to include pregnancy in their sickness and disability plans. ${ }^{139}$ At the same time, however, the focus on male-female comparisons caused some employers to cut back on maternity provisions, such as the availability of lengthier leaves than were offered for most other disabilities. ${ }^{140}$ These generous policies were probably more responsive than sick leave periods to the actual physical and emotional needs of pregnant workers, their children, and other family members. ${ }^{141}$

On the other hand, the special treatment approach, while perhaps

gender classifications, even though they do not include all women at any given moment. Nonetheless, the classification chosen by the Court-pregnant persons and nonpregnant persons-is one of the many possible validly descriptive ways of classifying the groups in Geduldig and Gilbert. This simply shows the indeterminancy of most ways of classifying people.

138. The historian Ellen DuBois has noted the similarity of the current debate over maternity leave to the debate over protective wage and hour laws that occurred in the early part of this century, which she characterizes as a debate between "egalitarian-feminism," which stresses that women are just like men and thus should have the rights accorded to men, and "domestic-feminism," which stresses the special and different interests and needs of women and the consequent way in which men's rights and needs cannot necessarily define what women want and need. Feminist Discourse, supra note 135, at 64-68 (remarks of Ellen DuBois); see also A. Kessler-Harris, supra note 17, at 180-214, where the arguments summarized by this historian pro and con protective legislation sound startlingly similar to the present debate.

139. See Maternity Policies, supra note 9 , at 43 ; Catalyst, supra note 9 , at 6 .

140. Maternity Policies, supra note 9 , at 111,118 . The approach of comparing pregnancy with disabilities has exacerbated the gap between policies in this country and in others. The disabilities approach has been one of the reasons why the United States lags so far behind the rest of the industrialized world in its maternity and parenting policies. Id. at 144-46. Concern for parent-child development has rarely been a motivating concern of labor policies and their design in the United States. Id. at 145.

141. Id. at 111,118 . 
leading to the desirable outcome of longer maternity leaves than are now routinely available in this country, is a double-edged sword. As long as there are similarities to be perceived between the effects of pregnancy and other conditions, women may be regarded as receiving an undeserved benefit. This may produce resentment among fellow employees, cause employers to avoid hiring women because of fears that they will be more expensive workers to carry, and further entrench the unhelpful stereotype that women are frail and in need of paternalistic protection. ${ }^{142}$ Avoiding this danger in the refuge of the equal treatment approach does not solve the problem, because many of the employers with the least adequate illness, disability, or maternity policies are in small businesses or the service and retail sectors where a majority of working women are found. ${ }^{143}$ Here, the comparative focus of the PDA founders because there are few or no men for comparative purposes. ${ }^{144}$ Nevertheless, equal treatment advocates fear that the additional costs of employing pregnant women that can flow from special treatment will lead employers to shy away from hiring anyone they think is likely to become pregnant. However, the supposedly neutral solution proposed by equal treatment advocates could have the same adverse impact on pregnant women as special treatment due to cost factors. If a company increases its allowed disability leave time to encompass time for maternity, or makes parenting leaves available to workers of both sexes, far more women than men will avail themselves of the benefit. ${ }^{145}$ Thus, it will still be more expensive to employ women, in the sense that women may take more time off from work.

The competing strands within equality theory of equal outcome versus equal opportunity give the entire analytic framework an internally contradictory quality. Thus, the doctrinal framework itself does not provide a basis for choosing between the strands in any particular situation. ${ }^{146}$ Two important lessons from history are that women have not been treated the same as men, and that women have lost their jobs and benefits due to pregnancy. So, choosing the equal treatment approach undermines the equal opportunity value, and choosing that

142. See, e.g., Williams, Equality's Crisis, supra note 100, at 196.

143. Maternity Policies, supra note 9 , at $49,52,57$.

144. For this reason, the parity approach of the PDA may be limited in what it can accomplish in sex-segregated workforces. See Note, supra note 104, at 950-52.

145. The Catalyst Report on Maternity/Parental Leaves reports that few men use the paternity leave available to them. Catalyst, supra note 9 , at 5 . The findings in Maternity Policies, supra note 9 , at 62 , suggest the same lack of interest or use by men. The experience in Sweden reveals that far more women than men use the leave which is available to parents of either sex. See Williams, Equality's Riddle, supra note 12, at 378 .

146. Cf. Kennedy, supra note 113, at 1711-12 (debate over whether "real equality" is equality of opportunity or equality of enjoyment of the good things in life cannot be resolved by the rules-standards or form-substance dichotomies, but rather presents "an invitation to choose between sets of values and visions of the universe"). 
value undermines the equal treatment ideal. ${ }^{147}$

This realization demonstrates that equality analysis is neither objective nor value neutral. The outcome of the analysis which asks whether someone is different or the same, or similarly or differentially situated, depends entirely on the characteristic or factor selected for emphasis. This selection is a highly political, value-laden choice, determined by one's world view and perspective. ${ }^{148}$ The supposedly objective strictures of equality analysis did not screen out from the factors of decision the world view apparently held by a male majority of the Supreme Court that women do and should disengage from the workplace and its attendant benefits when they become pregnant. ${ }^{149}$ Thus, the "neutral" command to treat likes alike has not constrained the use of judicial power to perpetuate the subordination of women.

2. Equality Analysis and Homogeneity: The Male Norm.-A second feature of equality analysis more troubling than its indeterminacy is the way it views differences among people. ${ }^{150}$ A fundamental, but too often unquestioned, assumption of our cultural and political tradition is the ideal of homogeneity. When the historical content of the homogeneous ideal is examined, it becomes apparent that it is hardly an objective, inclusive ideal. ${ }^{151}$ The defenders of the American ideal of homogeneous equality wrote in sweeping terms about the commonali-

147. For an intriguing attempt to move outside the circularities of equality theory and into the realm of philosophy, morality, and political visions, see Wasserstrom, supra note 98 .

148. Indeed, the whole notion of objectivity is highly problematic, since we each inevitably see the world, and define others, according to our own perspective or subjectivity. Subjectivity and objectivity have been described as "dangerous supplements" to each other: rather than presenting a clear dichotomy, they are in relationship to each other and are intermixed, and each threatens, or renders problematic, the other. Frug, The Ideology of Bureaucracy, 97 Harv. L. Rev. 1276, 1288-91 (1984) (drawing on J. Derrida, Of Grarnmatology (G. Spivak trans. 1976)). When applied to the idea of our samenesses and our differences, what this means is that while two people may "share much in common ... [their] differences rather than [their] commonness can always be emphasized. If they are, the notion that we together create a world of objectivity can be destroyed simply by emphasizing the differences embodied in our particularity. The world of individual subjectivity is a necessary part of the objective world but one that is dangerous to any sense that 'objectivity' is possible." Id. at 1291.

149. The Supreme Court's gender equality jurisprudence in areas other than pregnancy also shows inconsistencies that stem from world views about the inevitability of, or rightness of, socially constructed gender differences. See Freedman, supra note 51; Wildman, The Legitimation of Sex Discrimination: A Critical Response to Supreme Court Jurisprudence, 63 Or. L. Rev. 265 (1984).

150. Indeterminacy will characterize most legal doctrines, or attempts to provide theoretical frameworks for rendering legal decisions as we know them. In my view, this is because certain conflicts in values or needs are inherent in human life, rather than being uniquely tied to any particular way of analyzing and trying to resolve the conflicts of human life. See infra notes 184, 233-35 and accompanying text; Sparer, Fundamental Human Rights, Legal Entitlements, and the Social Struggle: A Friendly Critique of the Critical Legal Studies Movement, 36 Stan. L. Rev. 509 (1984).

151. For an historical examination of the ideal of homogeneity and its link to white, 
ties among American citizens, ${ }^{152}$ yet their descriptions bore a striking resemblance to the world of the white, anglo-saxon protestant male. The American melting pot has been a cauldron into which we have put black, brown, red, yellow, and white men and women, in the hope that we will come up with white men. The ideal of homogeneity has legitimated much invidious discrimination throughout our history. ${ }^{153}$ The ideal blinds us both to the fact and to the value of our diversity. Consequently, it marginalizes, disempowers, and renders invisible those such as women, who have seemed most unlikely to ever melt into the white male model of homogeneity. ${ }^{154}$

The ideal of homogeneous assimilation has been a motivating force behind our legal system's definition of equality as the similar treatment of those who are similar. The search for categories of similarity means that there must be a standard against which similarities are to be measured, and the choice of the standard will determine the nature of the outcome of the comparison. ${ }^{155}$ But, there is something inherent in the concept of a standard for assessment that views the standard as the norm, and everything that is dissimilar from the standard as the deviate "other."156 "Different" and "other" consequently have pejorative connotations in our tradition of equality jurisprudence.

The idea that to be "different" is undesirable leads to the "difference dilemma." 157 Our tradition of equality has too often meant preju-

anglo-saxon protestant, male values and experiences, and the way this has given content to our ideal of equality, see J. Pole, The Pursuit of Equality in American History (1978).

152. John Jay, writing in the Federalist Papers, described Americans as "[O]ne united people-a people descended from the same ancestors, speaking the same language, professing the same religion, attached to the same principles of government, very similar in their manners and customs ...." The Federalist No. 2, at 94 (J. Jay) (B. Wright ed. 1961). This theme was sounded again in the next century. Crèvecoeur lauded American society for creating "a new man" through a process that eradicated differences of religion, custom, and manners to achieve a relatively homogeneous society. See St. John de Crèvecoeur, Letters From An American Farmer 49, 54-59 (1968 ed.). At the time both these men extolled our homogeneity, blacks and Indians existed in large numbers in this country defying the reality of which they wrote. As waves of Asian, Eastern European, and Irish immigrants further eroded the veracity of the characterization, homogeneity nonetheless remained the predicate for equality. See J. Pole, supra note 151; Krieger \& Cooney, supra note 12, at 547-49.

153. Krieger \& Cooney, supra note 12 , at 549-50.

154. Cf. J. Pole, supra note 151 , at 148-213 (history of discrimination against blacks has its foundations on their perceived nonassimilability); Krieger \& Cooney, supra note 12, at 548-51 (hostility toward any particular group of immigrants is negatively correlated with their perceived assimilability).

155. For example, if color is the standard of measurement, then apples and oranges are different. But, if the standard for comparison is shape, or edibility, then they are similar.

156. Women, in the eyes of male-dominated society, have been the paradigmatic "other," and have suffered from the devalued status of being an "other." See S. De Beauvoir, The Second Sex (1952).

157. See Minow, Learning to Live With the Dilemma of Difference: Bilingual and Special Education, 48 Law \& Contemp. Probs. No. 2, at 157, 159 (1985). 
dice toward those whom the dominant group has labelled as different. Thus, to be considered different can mean being stigmatized or penalized. "Difference" is stigmatizing because the assimilationist ideal underlying our society's conception of equality presumes sameness. Thus, the recognition of difference threatens our conception of equality, and the proclamation or identification of difference can serve as a justification for existing inequities. ${ }^{158}$ On the other hand, to hide the fact of difference from the prevailing norm means being treated according to a "faulty neutrality," or a standard that, because it was not created with the difference in mind, advances the dominant group to the detriment of those who are not, in fact, like it. ${ }^{159}$

The special treatment/equal treatment debate reflects each side of the difference dilemma. The equal treatment position, by emphasizing sameness, is designed to avoid further instances of discrimination in the male dominated and defined workplace because of ways in which women are different from men. The special treatment position recognizes the disadvantage of this emphasis on sameness, which is to recreate and entrench instances of discrimination that occur because the standards of the workplace have not been determined according to the needs and perspectives of women. To be treated as if you were the same as a norm from which you actually differ in significant ways is just as discriminatory as being penalized directly for your difference.

The very idea of a norm implies that whatever is considered "normal" can take on a quality of objective reality, so that it is no longer possible to see that the standard of measurement reflects simply one group of qualities out of the infinite variety of human experience. The qualities chosen as the standard for measurement for legal equality analysis have been determined by those who have had the power to define or to imprint their view of what is real, important, and normal, on others. ${ }^{160}$ In our society, that power has always been held by white men, because men have largely held control over institutions with the power to define. Men have defined desirable human traits in their own image, according to their own world view. They have then reinforced this self-referential standard as the objectively inclusive norm by either failing to study the experiences of others, ${ }^{161}$ such as women, or by viewing those experiences, when they did examine them, as pathologi-

158. This is why some feminists have reacted so strongly to the work of Carol Gilligan, which explores differences in the moral orientations of men and women. C. Gilligan, In a Different Voice (1983); see, e.g., Kerber, Greeno, Maccoby, Luria, Stack \& Gilligan, On In a Different Voice: An Interdisciplinary Forum, 11 Signs 304 (1986).

159. Minow, supra note 157 , at $159-60$.

160. See, e.g., MacKinnon, supra note 5, and MacKinnon, Feminism, Marxism, Method and the State: Toward Feminist Jurisprudence, 8 Signs 635 (1983), where she describes the way in which men have used their power to define women's experience, sexuality, and needs.

161. The work of C. Gilligan, supra note 158 , chronicles the phenomenon of the invisibility of the experiences and perspective of women. 
cal. ${ }^{162}$ Men have then defined and structured institutions, such as the family and the workplace, according to their own situation and needs. ${ }^{163}$ The way in which the structure of institutions then affects people's lives becomes understood as a natural consequence of differences, rather than as attributable to the directions that may be imposed on us by structural inequities. For example, the notion of the home and work as disconnected, incompatible separate spheres, with the private sphere occupied almost exclusively by women and the other by men, has been viewed as a natural, biologically based dichotomy. The way in which each institution has been socially constructed to bind its occupants to it has only infrequently been subjected to critical analysis.

The role of men in defining the standard of normalcy and in assigning significance to female differences, means that the whole premise of our equality jurisprudence is whatever is male is the norm. ${ }^{164}$ Thus, the questions asked are whether women are like men, or when, and on what terms, women should be allowed into the male world where, if they can act just like men, they can succeed. The equal treatment/special treatment debate reflects this focus on a male-defined norm. The formal equality approach tells us specifically to treat women the same as men, so that women can have the same opportunities men have had to compete in the male-valued work world, and so that women can escape the female populated, and male-devalued, home world. Thus, it implicitly accepts the male norms of "competition" and "suc-

162. The work of Sigmund Freud is a classic example of the pathological perspective. See Freud, Lecture on Femininity, in New Introductory Lectures 112 (J. Strachey ed. 1965).

163. Even when the institution is one to be occupied largely by women, such as the family and motherhood, or is one that is of crucial concern to women, such as female sexuality, men have often done the defining according to their own needs, desires, or conceptions. Women then internalize these norms, and seek to fulfill and perpetuate them as well. See, e.g., S. Brownmiller, Femininity (1984) (notions of feminine behavior, roles, appearance, and aspirations); A. Rich, supra note 91 (the institution of motherhood); sources cited supra note 160 (female sexuality). Although many sex-based discrimination cases have involved men seeking access to benefits or preferences accorded to women ostensibly to overcome past discrimination against women, see, e.g., Heckler v. Mathews, 465 U.S. 728 (1984); Califano v. Webster, 430 U.S. 313 (1977); Schlesinger v. Ballard, 419 U.S. 498 (1975); Kahn v. Shevin, 416 U.S. 351 (1974), or men seeking to be treated like women, often in the family setting, see, e.g., Caban v. Mohammed, 441 U.S. 380 (1979); Parham v. Hughes, 441 U.S. 347 (1979); Orr v. Orr, 440 U.S. 268 (1979); Stanley v. Illinois, 405 U.S. 645 (1972), these cases still reflect the male norm at work. Each of the challenged policies reflected sex role stereotyping based on the ideology of separate spheres, with almost exclusively male legislators or judges or administrators paternalistically deciding what women are and what they need. The fact that there are some men willing to challenge the norms, particularly in the family arena, and to point out that these norms can, in fact, harm men, does not mean that powerful social norms based on men's traditional predominance in the public sphere are not still prevalent. See Kay, Models of Equality, 1985 U. Ill. L. Rev. 39, 69-70, 75-76 (1985).

164. See Scales, supra note 51 , at $427-28$. 
cess." "To demand only the chance to compete is to embrace the status quo in a way that tends to sanction oppressive arrangements-for example, the necessity of choosing between children and career."165 In this way a focus on equal treatment accepts the idea that work and family are dichotomous spheres, and asks primarily that women be allowed out of one world and into another. ${ }^{166}$

There seems no way out of the male norm for the equal treatment position, since its insistence on comparisons runs up against the problem that in the legal system men are the referent against which all comparisons are made. One wonders why those who appreciate the inadequacy of the male norm for accommodating and measuring women adhere to a doctrinal framework that is designed only to compare against the norm, and not to question it. Equal treatment proponents might respond that they are questioning the assumption that the norm is male by pointing out all the relevant ways in which women are just like men. The notion of comparison means that many male judges or legislators will be able to perceive the ways in which women are just like men only when the particular female quality under scrutiny has not been devalued or viewed as an incapacity in the male world according to the male definition of the world's requirements. Categories such as childrearing, sexuality, and the consequences of pregnancy, which have been drilled into us as biologically determined differences, ${ }^{167}$ will remain particularly resistant to being put into the male-focused sameness classification.

The special treatment view does not entirely escape the male norm, either. In many respects the options given to women by equality analysis "of either being the same as men or being different from men are just two ways of having men as your standard." 168 Something like maternity leave is a "special" right only because it is not something men need. It is not a "male" right. With male as the reference point, the label "special," or "for women" takes on a pejorative cast because

165. Id. at 427 .

166. Some of those who advocate equal treatment as a legislative and litigation strategy have noted the male biases of the workplace and have called for policies, such as parenting leave and flexible time or location arrangements, designed to allow women better to accommodate their home and work responsibilities. See, e.g., Taub, supra note 40; Williams, Equality's Riddle, supra note 12.

167. Although the ability to become pregnant is clearly biologically determined, what is socially constructed are our ideas about the effects of pregnancy on a woman's ability to participate in the workforce, as well as our ideas that pregnancy makes women better suited for childrearing, and that because of its differential biology, reproduction is something that principally affects and concerns women, rather than men.

168. Feminist Discourse, supra note 135, at 21 (remarks of C. MacKinnon). MacKinnon relates this constant use of male as the reference point to hierarchy and the powerlessness of women. She argues that " $[\mathrm{m}] \mathrm{en}$ are set up as a standard for women by saying either: 'You can be the same as men, and then you will be equal,' or, 'You can be different from men, and then you will be women.' "Id. 
of the history of glorifying that which is male and devaluing the experiences and qualities of women.

Simply by focusing on women as women (as unlike men) and calling attention to their unmale needs, the special rights strategy may reinforce the stereotype of pregnancy as a woman's problem. This focus on pregnancy diverts attention from the ways in which other aspects of the workplace besides disability have been defined by men with men in mind. ${ }^{169}$ This can reinforce the disparity of roles, and the relegation of women to the confining institution of motherhood ${ }^{170}$ and the separate realm of the home. The special treatment approach may help perpetuate the separate spheres ideology, both because it can be interpreted as accepting that women, as childbearers, are and will always be the primary childrearers, ${ }^{171}$ and because it leaves unchallenged workplace values in areas besides childbearing that stem from the separate spheres. The special treatment approach thus has a tendency to define the problem as figuring out what female needs must be accommodated by, or incorporated into, the male workplace so that women will be better able to compete with men according to the existing value structures.

169. In her latest work, Ann Scales has acknowledged this limitation in the "incorporationist" view that she proposed. (Since pregnancy and breastfeeding are the only true biological differences in reproduction, "incorporate" these female needs into the workplace and the existing model of equality. See Scales, supra note 51.)

Incorporationism presumes that we can whip the problem of social inequality by adding yet another prong to the already multi-pronged legal tests . . . [and thus] suffers from the same lack of vision as the "equal rights/special rights" debate. Both presume that male supremacy is simply a random collection of irrationalities in an otherwise rational co-existence. Both presume that instances of inequality are mere legal mistakes-a series of failures to treat equals as equals, which we can fix if we can just spot the irrationality in enough cases. ... By trying to make everything too nice, incorporationism represses contradictions. It usurps women's language, in order to further define the world in the male image; it thus deprives women of the power of naming. Incorporationism means to give over the world, because it means to say to those in power, "we will use your language and we will let you interpret it."

Scales, The Emergence of Feminist Jurisprudence: An Essay, 95 Yale L.J. 1373, 1382-84 (1986) (footnotes omitted).

170. For expositions on the institution of motherhood, see A. Rich, supra note 91 ; A. Dally, Inventing Motherhood (1982).

171. I do not mean to suggest that this view is universally held by special treatment advocates. There are suggestions in the work of $\mathrm{E}$. Wolgast, supra note 111 , that she may accept women as the primary childrearers. Ann Scales, on the other hand, has been careful to point out that pregnancy and breastfeeding, and not suitability for raising children, are the only true differences. Scales, supra note 51 , at 435 ; see also id. at 430-34 (criticizing the bivalent view proposed by Wolgast). In her subsequent work, however, Professor Scales has described her earlier view about these two differences being the only ones with which the law should deal, as opposed to the more "subjective" differences of stereotype, as an "unnecessarily reticent" limitation. Scales, supra note 169 , at 1381 n.46. She now urges that "[a] committment to equality requires that we undertake to investigate the genderization of the world, leaving nothing untouched." Id. at 1382 . 
These tensions in the equal treatment/special treatment debate are a direct result of the male norm in equality theory. After all, the special rights view contradicts the equal treatment view only if we take as the limit of possibilities those rights and expectations already created by and for the dominant group. ${ }^{172}$ When we stop accepting men's needs as determining all desirable "rights" for both women and men and thus as constituting the standard for equality analysis, we will cease being so concerned about whether maternity leave is a "special right" because it is not male oriented.

The focus of equality analysis on comparisons with the male norm makes it well-suited for perpetuating existing distributions of power. ${ }^{173}$ Because those in power are the ones making the attribution of difference, they will see themselves as normal and everyone else as the undesirable other. ${ }^{174}$ One need only make a cursory examination of the pregnancy cases, and the assumptions that continue to permeate the law, to grasp this point. ${ }^{175}$ Indeed, equality analysis has sometimes been used to legitimate discrimination rather than successfully to eradicate it. ${ }^{176}$

If the effort to eliminate gender hierarchy is to bear fruit, the male norm must constantly be questioned. We must redefine the standards against which humans are evaluated to be more inclusive of the full range of human experience and perspective. ${ }^{177}$ We must examine the ways in which institutions such as the workplace and the family have been structured with the male norm in mind. Because equality analysis cannot give us the tools to perform these tasks, we must transcend it and try to think about these problems in other ways. Both equal treat-

172. Martha Minow develops a similar idea for understanding our approaches to the "rights" of the mentally retarded. M. Minow, Legal Treatment of Mental Incompetence: Problems of Status, Classification, and Relationships 18-19, 53 (unpublished manuscript December, 1985) (copy on file at the offices of the Columbia Law Review).

173. Equality analysis is ill-suited for questioning the norm, because all that it designed to do, and thus enables us to do, is to make comparisons with the given norm. As Catharine MacKinnon has said, "[women] can play with the boys but we cannot question competition as a measure of merit. We can think but we are not allowed to question objectivity as the measure of what we know." Feminist Discourse, supra note 135, at 23 (remarks of C. MacKinnon). MacKinnon has also developed her analysis of the ways in which women must buy into the norms of the workplace in her book Sexual Harassment of Working Women (1979). Women not only have not had the power to question values such as the definitions of competition and success, but they have had to internalize and accept these workplace values themselves in order to succeed. This reality will make it all the harder to change the prevailing values.

174. See M. Minow, supra note 172 , at 28.

175. See supra notes 16-106 and accompanying text.

176. See Freedman, supra note 51; Freeman, Legitimizing Racial Discrimination Through Anti-Discrimination Law: A Critical Review of Supreme Court Doctrine, 62 Minn. L. Rev. 1049 (1978); Wildman, supra note 149.

177. For an effort to do so in the realm of moral development theory, see C. Gilligan, supra note 158; Gilligan, Remapping the Moral Domain: New Images of Self in Relationship, in Reconstructing Individualism 241 (I. Watt ed. 1986). 
ment and special treatment proponents are trapped in a circular debate over what is a relevant sameness and what is a relevant difference, and energy is being devoted to fighting this battle up to the Supreme Court, rather than to working together to achieve meaningful change. Instead, feminists should address, in political terms that openly acknowledge the values at stake, what they really want and what women needstructures that recognize that our family lives and work lives are importantly interconnected and will always affect each other, and devices for legal decisionmaking that do not always require hierarchical value to be assigned to various human conditions or experiences.

3. Equality Analysis and Responsibility.-Equality analysis is also limited because it is only as useful a tool for changing the status quo as the conceptions of human rights ${ }^{178}$ and human nature that underlie it. ${ }^{179}$ Our legal system has tended to view the person who holds rights, including the right to either equality of opportunity or equality of outcome, as an isolated, self-sufficient, autonomous actor. This conception of the self has little room in it for recognizing and embracing interconnectedness with and responsibliity to others. The relationship between this view of human nature and equality doctrine is that in building on a conception of isolated autonomy, the ideal of equality searches for an irreducible and universal aspect of humanity. This requires a focus on sameness and a desire to obliterate differences. Sameness means generality; it means removing individuals from their

178. Given that equality is closely linked with rights, Professor Peter Westen has advanced the idea that "equality" is an empty concept, because in his view all debates phrased in equality terms in essence boil down to debates about rights. Westen, The Empty Idea of Equality, 95 Harv. L. Rev. 537 (1982). While I agree that equality analysis is inextricably tied to, and limited by, existing concepts of rights, and that talking in terms of equality can obscure underlying issues of rights or needs, see infra notes 185-93 and accompanying text, I do not conclude from these observations that equality is an idea without content. Much of my preceding discussion is intended to illustrate that the comparison orientation of equality analysis does have content. The search for similarities and differences limits one's view of the problem and thus has an impact on the issue under examination. Moreover, the idea of a norm, or a standard of measurement, that underlies equality analysis, gives content to the idea of equality-it comes to mean assimilation to the characteristics defined by those with the power to define the norm. Professor Westen illustrates his view by suggesting that the proposed Equal Rights Amendment would have had the same import if it had simply been the Rights Amendment, declaring that "[r]ights under the law shall not be denied ... on account of sex." Id. at 594. This latter formulation, however, might have freed our thinking from the strictures of comparing women to men and enabled us to talk more openly about what rights women as women, rather than as not men, might need in our society.

179. Cf. Unger, The Critical Legal Studies Movement, 96 Harv. L. Rev. 561, 602-16 (1983), where Professor Unger critiques equal protection doctrine for being based on a discredited underlying view that society is made up of free, autonomous individuals whose life chances are not particularly affected by their relative positions in a social hierarchy. This underlying view sees legally defined rights as doing no more than facilitating the exercise of individual free will, and not as enhancing any particular set of interests or power groups. See also Hutchinson \& Monahan, The "Rights" Stuff: Roberto Unger and Beyond, 62 Tex. L. Rev. 1477, 1510 (1984). 
context and connection, so that they are like all others in being nothing more than their self-contained and autonomous essences. ${ }^{180}$ Difference, on the other hand, can be troublesome precisely because it requires thought about connections and context. Autonomy, which is held out as the ideal for decontextualized human beings, is defined as the realization of self-fulfillment guided by the ultimate authority of self-judgment without interference from others.

This underlying view of human nature has produced a negative, highly individualistic definition of rights. ${ }^{181}$ The critique of rights analysis has been thoroughly developed elsewhere, ${ }^{182}$ including from a feminist perspective. ${ }^{183}$ I need only recount it here briefly. The conception of abstract individualism leads to a definition of freedom as noninterference from other individuals. Rights are seen as necessary to protect our glorious isolation-to provide just the measure of security from others that is necessary to guarantee freedom from others and from the state. Of course, one can never tell in the abstract just what the necesssary measure of freedom is-hence, there exists what has been called the "fundamental contradiction" of liberalism, the conflict between our need for freedom and our need for security. ${ }^{184}$ The rights that we have are largely negative and inward looking, in the sense that

180. I am indebted to Clare Dalton for this analysis. See C. Dalton, Remarks on Personhood (delivered at Association of American Law Schools panel, Jan. 5, 1985) (unpublished manuscript) (copy on file at the offices of the Columbia Law Review).

181. The underlying view of human nature also has elements of sex bias in it. See A. Jaggar, supra note 91 , at 46-47, 173-202. It posits that the mind is separable from the body, and that what distinguishes human beings from other forms of life is their "rational" capacity for a particular kind of abstract, objective mental activity. This view stems from Cartesian philosophy. Id. at 39-40. The notion that the family world-or the world where bodily concerns predominate-is separate from the mental world of public pursuits, flows from this philosophy of normative dualism. This philosophy has caused women to be devalued, because women have traditionally been linked with the realm of the body and assumed to be incapable of the exalted forms of rational thought. Id. It has also led to devaluing ways of thinking, such as intuition, empathy, and resonance with experience, that produce far more focus on the existence of and concerns of others than is provided by abstract rational individualism. For example, when Freud wrote that women had an underdeveloped sense of justice, he conceived of justice as a highly abstract idea that requires drawing hierarchical, noncontextual distinctions between rights. But, when justice is conceived of differently, a female-oriented way of thinking can appear quite just. C. Gilligan, supra note 158, at 6-7, 18, 30, 100. Since the theory of human nature underlying traditional liberal rights and equality theories denigrates the experiences and qualities associated with women, it can be considered a sex-biased theory. A. Jaggar, supra, at 46-47.

182. See generally R. Unger, Knowledge and Politics (2d ed. 1984) (critiquing traditional liberal view of rights); Kennedy, The Structure of Blackstone's Commentaries, 28 Buffalo L. Rev. 205 (1979); Singer, The Legal Rights Debate in Analytical Jurisprudence from Bentham to Hohfeld, 1982 Wis. L. Rev. 975; Tushnet, An Essay on Rights, 62 Tex. L. Rev. 1363 (1984); Unger, supra note 179.

183. See, e.g., A. Jaggar, supra note 91, at 27-48, 185-203; Olsen, supra note 112.

184. Kennedy, supra note 182, at 212-13; Singer, supra note 182; Sparer, supra note 150 , at $519,547-50$. 
they are designed to keep us apart in our isolated selves by proscribing certain activity and setting out protected zones of noninterference. We mostly have rights "against," rather than affirmative conceptions of rights "for," or rights "to."

The inadequacies of these underlying visions of human nature and rights for describing human reality are readily apparent. The most fleeting contemplation of reproductive biology demonstrates that individual self-sufficiency is neither possible nor desirable. At the species level, we are biologically interdependent. To a large extent, many of us, as individuals, are also emotionally interdependent. Our conceptions of self worth more often come from our attachments to other human beings, from the knowledge that others care about us, need us, like us, or respect us, than from an unanchored, decontextualized, intrinsic sense of self worth. ${ }^{185}$ Moreover, the conception of autonomy as self-definition is challenged by the recognition that our desires and values are often socially constructed. ${ }^{186}$ The theory of equality that operates on abstract individuals suffers from a glaring flaw-real human beings have a determinate race, age, and sex. Thus, when considering what equality is to mean for women, we cannot be blind to the fact that the law operates on gendered subjects.

Thus, our conception of rights and equality ignores the many human needs apart from disconnection and non-interference. The notable absence of values of interconnectedness and care in our system of rights, and the tendency of equality analysis to overlook context in its search for essential similarities, suggest that these analytic approaches may only reflect the male aspect of human experience. It is the male aspect of human experience because men are generally removed from bodily concerns such as preparing food for the table and assuring clean clothes in the drawer, and have been removed from human experiences that can foster a sense of interconnectedness, such as birth and childrearing. Thus, it is much easier for men to conceive of themselves as disconnected, autonomous beings. ${ }^{187}$

The limits of our reform imaginations are usually defined by the search to extend more rights to people. As long as the concept of rights remains based on the value of noninterference, so that affirma-

185. As Gerald Frug has pointed out, "we can define ourselves only through relationships with the world in which we live. To find ourselves, we seek ideas through the commonly created world of language, knowledge through interaction with others, and an affective life through loving and being loved by those close to us." Frug, supra note 148, at 1290; see also Kennedy, supra note 182, at 211-12 ("Others (family, friends, bureaucrats, cultural figures, the state) are necessary if we are to become persons at allthey provide us the stuff of ourselves and protect us in crucial ways against destruction.").

186. Feminist psychologists, for example, have emphasized sex role conditioning as crucial to our conceptions of gender and its significance. See N. Chodorow, supra note 91; D. Dinnerstein, The Mermaid and the Minotaur (1976).

187. See N. Chodorow, supra note 91; C. Gilligan, supra note 158. 
tive rights such as the right to reasonable maternity leave are a distrusted anomaly in our legal system, ${ }^{188}$ we can travel only so far in restructuring institutions. Since equality analysis is fundamentally designed to do no more than extend equal rights to individuals, it too suffers from the limited transformative potential of our current conceptions of rights.

The drawback of limited horizons is reflected in the tendency of equality analysis to divert attention from and to obscure the deeper nature of the problem leading to the plea for equal rights. ${ }^{189}$ This has occured at two levels. First, the search for categories of sameness and difference fails to appreciate the full context of the social conditions that provoke an equality claim. The pregnancy cases are notable for their absence of attention to context. The judges reviewing airlines' grounding policies have rarely put the issue in the context of the initial refusal to hire married women, the former policy of firing pregnant women, and the final response of removing them from flight duty. ${ }^{190}$ The judges reviewing exclusionary policies in the chemical industry have often failed to place that issue in the context of formerly all male, high paying jobs that had grudgingly been opened up to women, coupled with the biases of science that tend to assume that all reproductive risks visit women rather than men. ${ }^{191}$ When the Supreme Court reviewed the exclusion of pregnancy from disability plans, it did not broaden the inquiry of what "uniqueness" implied for the plans' fiscal integrity to encompass the decades of blatantly hostile, stereotyped, and penalizing treatment of pregnant women in the workplace. It is easy to come away from these cases that talk about the validity of differential treatment with a gloomy sense that the courts fundamentally missed the point. ${ }^{192}$

188. The Supreme Court's hostility to the idea of requiring employers to provide maternity leave under existing disability plans, see Geduldig v. Aiello, 417 U.S. 484 (1974); General Elec. v. Gilbert, 429 U.S. 125 (1976), may be attributable to the resemblance between maternity leave and the notion of affirmative rights. The Court has often narrowly interpreted statutes that could be seen as extending affirmative rights. Perhaps the best recent example is in Pennhurst State School \& Hosp. v. Halderman, 451 U.S. 1 (1981). In that case the Court held that the Developmentally Disabled Assistance and Bill of Rights Act did not create substantive rights. The "Bill of Rights" section of the Act said that the mentally retarded had a right to treatment and services in a setting "least restrictive of . . personal liberty." Developmentally Disabled Assistance and Bill of Rights Act, 42 U.S.C. $\$ 6010$ (1976). The Court viewed this language as merely precatory, rather than as establishing substantive rights, because of the strong presumption against Congress' creating affirmative rights that might impose financial obligations on states, 451 U.S. at 15-22.

189. Fran Olsen has pointed out that it is necessary to challenge the social conditions that make rights seem necessary. Olsen, supra note 112 , at 430 .

190. See supra notes $69-73,79-80$, and accompanying text.

191. See supra notes $60-65$ and accompanying text.

192. This is true in gender discrimination cases outside the pregnancy area as well. Not only has the Court failed to look deeper than doctrinal categories into the underlying social inequities, but it has frequently denied the need to do so. For example, in Personnel Adm'r v. Feeney, 442 U.S. 256 (1979), which challenged a civil service vet- 
There is yet a deeper level, however, that has been obscured by equality analysis. The context in which gender hierarchy problems arise includes the need to question why we value some kinds of human activity as "work" and not others of equal societal value, ${ }^{193}$ and why some kinds of "work" are considered appropriate for one sex rather than the other. It is also necessary to question why we view those who are engaged in the remunerative kinds of work as abstract individuals with little responsibility to each other and with totally separate lives "outside" work. A central aspect of the problem that eludes equality analysis is the maintenance of separate spheres of work and home, and the devaluation of the home sphere and values associated with it in the work world. Consequently, the values of interdependence, care, and responsibility that are characteristic of the home sphere are absent from the public sphere of the workplace and the legal system. ${ }^{194}$

\section{Suggestions for Transcending Equality Analysis}

The effort to fit all our approaches to gender problems into the current framework of equality may obscure the deeper context of the issues and may curtail our thinking about the means for addressing underlying issues such as the implications of the ideology of separate spheres. Although it is possible to infuse the word "equality" with a conception that is more sensitive to the bias embedded in structures and values than the comparative approach, ${ }^{195}$ at present it may be eas-

eran's preference statute, the Court denied that the history of discrimination against women in the military was on trial. Id. at 278. In Schlesinger v. Ballard, 419 U.S. 498 (1975), the Court again failed to scrutinize the different opportunities available to women in the military in the process of upholding a sex-based classification as justified by those different opportunities. In Michael M. v. Sonoma County Superior Court, 450 U.S. 464 (1981), in the process of upholding a statutory rape scheme that applied only to males, the Court failed to consider the differing conceptions of appropriate sexuality applied to young men and to young women, and the way in which this has stereotyped and constrained women. See Olsen, supra note 112. As Stephanie Wildman has said,

[ $t$ ] he stereotyping of women into dependent roles, the stereotyping of fathers as having minimal involvement with their children, the right of women to control their destiny, the role of pregnant women in the workforce, the economic disadvantaging of women in the workforce, and discrimination against women in the military, present a litany of real grievances about the role assigned to women in this culture. However, when translated into legal language these claims become a battleground of due process versus equal protection, strict scrutiny versus reasonable basis, penumbras of the Bill of Rights, and a questioning of the very existence of sex discrimination. The abstraction of these very real social problems into this legal vocabulary has diverted attention from the immediate goal of combating sex discrimination.

Wildman, supra note 149, at 286-87 (footnotes omitted).

193. For a critique of both Marxist and liberal tendencies to accept the idea of divisions between productive and reproductive work, see A. Jaggar, supra note 91, at 138-44.

194. See, e.g., Olsen, supra note 3.

195. See C. Mackinnon, supra note 84, at 101-27 (1979) (proposing an "inequal- 
ier to make advances towards the goal of meaningful change in social structures and attitudes if we try not to think about problems such as accommodating pregnancy as "equality" problems, but instead look at them in a new light. I certainly have no objection to the ideal of equality, and think that the principle should be maintained in those situations where the traditionally disempowered are seeking access to the privileges of the powerful, without seeking to change the existing value structures of those privileges. Nevertheless, the current conception of the ideal articulated by the equality doctrine has taken on a meaning that keeps referring us to a male norm. The word has come to equate difference with stigma, and to exalt similarity as the ideal. In the process, the idea of "equality" overlooks the socially constructed nature of difference. The inherited language of equality does not easily convey the meanings of those who urge a broader definition of "equality."196 The language seduces us into the circularity of the special treatment/equal treatment debate. Thus, we need to acknowledge that the borrowed language ${ }^{197}$ is no longer well suited to expressing many of the problems women must address, now that women have advanced in ever increasing numbers into previously male domains and privileges. ${ }^{198}$ Once our society's conceptions of sameness and difference,

ity" rather than a "differences" approach, in which courts strike down classifications or policies that contribute to the subordination of women); Fiss, Groups and the Equal Protection Clause, 5 Phil. \& Pub. Aff. 107, 147-77 (1976) (equality doctrine should reach conduct, whether stigmatizing or not, that disadvantages groups from fully participating in society); Note, Toward a Redefinition of Sexual Equality, 95 Harv. L. Rev. 487 (1981) (proposes moving beyond the antidiscrimination principle to permit examination of social decisions that turn perceived or actual differences into handicaps, so that inquiry becomes whether unequal distribution of social rewards should track these differences).

196. Professor Chris Littleton, in her student Note, admitted that her proposal to move beyond the assimilation model by questioning the social conditions that make certain differences operate as handicaps would constitute a complete redefinition of "equality." Note, supra note 195, at 507-08. She also admitted that "[a] coherent redefinition of the meaning of sexual equality may not be possible at the moment ...." Id. at 507. What I fear is that by trying to fit a redefinition into the existing terminology, one becomes vulnerable to the objection that the proposed redefinition is not what "equality" as pronounced in the existing antidiscrimination doctrine means. This is especially true at a time when, in the context of sex discrimination courts are adopting narrower views of the definition of discrimination to the point of virtually abandoning the disparate impact theory as a viable tool for ferreting out the discriminatory impact of subjective criteria that may be male-biased in their underlying value structures. See, e.g., Spaulding v. University of Washington, 740 F.2d 686 (9th Cir. 1984) (disparate impact theory not available for a comparable worth claim), cert. denied, 105 S. Ct. 511 (1985); EEOC v. Sears, Roebuck \& Co., 628 F. Supp. 1264 (N.D. Ill. 1986).

197. I call the equality doctrine a borrowed language because litigators in the first sex discrimination cases looked to the race discrimination doctrine developed during the heyday of the civil rights movement. See Karst, supra note 108, at 470 .

198. " $[T]$ he limitations implicit in borrowed notions may divert attention from the difficult task of nurturing and articulating new ideas. Seeming to reflect an ineluctable reality, labels like sameness and difference may lull us into forgetting that such concepts 
male and female, have undergone some change, it may be profitable to start talking about "equality" again.

To move beyond the confines that equality analysis places on our imagination, it is necessary first to restate the social problem symbolized by inadequate pregnancy and parenting leave policies in the American workplace. The problem to be addressed through legal and institutional change is not simply, as equality analysis suggests, one of the failure to treat women similarly to men in the public sphere, or the failure to make some accommodating adjustments in the public sphere so that women can have the same opportunities or outcomes within that sphere as men. The problem is that the spheres of work and family have been viewed as separate in a way that has excluded the values, needs, and perspectives of one from recognition in the other. This dichotomy of values has limited the ability of both women and men to become fully realized interdependent human beings, because it has tolerated the assumption by employers and the rest of society that workers can be dealt with as disembodied from the entire context of their lives.

It has been assumed that women naturally are more suited for the home sphere. Consequently, they have been forced to primarily occupy that sphere, because of inhospitable structures and values of the work sphere and the tendency of our legal tradition of equality jurisprudence to view both the underlying structures and the divisions as normal. The separation has rendered working women's lives into a stressful, exhausting juggling act that leaves them little time or energy for feeling fulfilled and expanded by their dual roles and their relationships within each role. We do not conceive of work roles and home roles as integrated, mutually reinforcing experiences, but rather see them in competition with each other. The benefits to be gained from working are not seen as enhancing a woman's contributions to her roles as wife, lover, friend, or mother. The benefits from these latter roles of being sensitive to other's needs and of receiving the personal validation that comes from relationships are not seen as enhancing a woman's contributions to the work world.

The situation for men is similar in its detrimental effects. Men have been assumed naturally to occupy the public work world. Consequently, that world has been structured without regard to the needs and values of the family world, such as a recognition of the importance

have human authors and remain susceptible of revision. Overlooking this fact, the reformer may try to express new ideas through old terms illsuited to the task." Minow, Rights of One's Own (Book Review), 98 Harv. L. Rev. 1084, 1089-90 (1985).

Although women are now faced with issues for which the current model of equality may not be suited to accomplish necessary social change, that does not mean that the principle of equality should be completely abandoned. Rather, it is necessary to analyze the ultimate goal-mere access to male prerogatives, or a more profound change in values, structures, and policies-and equality analysis should be used only when, despite its limitations, it is tailored to the goal. 
of human interdependence and solidarity. The structures and values of the work world are built around the conception of atomized individuals, where freedom, such as freedom of contract, is viewed as a very individual matter that can be pursued outside of social context, and competition against others, rather than solidarity with others, is the ethic. These views have kept men as much out of the family world and out of touch with values of support and connection as they have kept women out of the work world. For men, too often it has not even been a matter of juggling, but of being forced to accept that the need to work reduces the kind of commitment one can make to family. This is as limiting for men as the opposite is for women, because our work and family, or our lack of them, are crucially interrelated defining aspects of our lives, our self-conceptions, and thus our prospects for fulfillment as members of the human community.

If we are going to have any success in tackling the problem of gender hierarchy and transforming the situations of both men and women, we need to focus not so much on traditional conceptions of equality, but on the values at stake in current structures and role conceptions. We need to focus on the falsity of the public-private dichotomy and the need to integrate the values and structures of both the public and home worlds accordingly. It is necessary to challenge openly certain assumptions about men and women that flow from the dichotomy, such as the definition of career commitment that allows work demands to crowd out other needs and the related assumptions that the career commitments of women are reduced by their family responsibilities or by their desire to give time to both worlds, ${ }^{199}$ and that men do not care as much as women about their families or human attachments.

To move towards this goal, and to transcend the limitations of equality analysis, we need to enlarge our legal discourse in two ways. First, it is necessary to devise a new approach to differences that sees them as relational and thus accepts them in a nonhierarchical, nonpejorative way. The approach must abandon total assimilation as an ideal and must strive to make the law sensitive to the way in which the perspective of the more powerful, the legal decision maker, can lead to attributions of difference. Second, we must supplement existing notions of rights as zones of noninterference, because interference is

199. It would seem that a woman who requests scheduling accommodations from her employer is actually demonstrating her sincere job commitment. She is showing that she has given mature thought to her numerous responsibilities and has realized that to continue giving top level performance to the job she must make adjustments in when she will be available to work. A woman who did not have a strong career commitment might not seek to remain in a demanding job. Employers should not blindly accept the stereotypes about career commitment that make it acceptable for a man to talk about his family in the office, but make it politically dangerous for a woman to show similar concern. Rather, they should realize that human beings of both sexes can be dedicated to their families and careers at the same time, but that doing so requires some adjustments in both worlds. 
not the only paradigm of human interaction. Human interaction can also mean support, enrichment, and the establishment of sustaining bonds of community. But, we must also struggle with the issue of how to draw lines between policies that respond to values of interconnection, and the need of people to maintain a zone to themselves, in order to avoid the problem of forced community. ${ }^{200}$

The difficulty of enlarging the meanings of the words and the conceptions of human nature underlying existing theories of equality and rights while using their language should not be underestimated. To solve these dilemmas and to work out completely how the law should respond to differences or view human needs is an enterprise larger than the scope of this Article. Indeed, problems such as the difference dilemma and the tension between the human need for interconnectedness and the need for individual space are perennial philosophical questions.201 Suggesting new ways to start thinking about these problems, however, will correct an imbalance in the ways the law presently conceptualizes them. Equality analysis currently approaches the problem of differences either by pretending they do not exist, or by stigmatizing those who are different; rights analysis is tilted much too far towards the solitary end of the individual-community continuum. Once the rethinking has begun, we can turn back to maternity policies in the workplace and suggest the kinds of policies and justifications for them that would flow from a new conception of differences and interconnection.

\section{A. How to Think About Differences}

The point of thinking about differences in a legal system that accepts human variety should be to try to avoid the dilemma of people being stigmatized or penalized by, or burdened in their access to, the domain of the "not different" by the fact of their difference. Gender differences should not burden women in the work world and keep men trapped in a world that denies to them the values of the home world.

Present equality analysis asks which differences count and which do not; or, what are the relevant similarities and differences? This ap-

200. Policies that appreciate the value of both community and diversity should be distinguished from the visions of traditional "strong" communitarian thinkers, such as Sandel. See, e.g., M. Sandel, Liberalism and the Limits of Justice (1982). "Strong" communitarians tend to embrace assimilation and homogeneity, and thus their ideal communities may, for some members, feel like forced communities. See Baker, Sandel on Rawls, 133 U. Pa. L. Rev. 895 (1985) (critiquing Sandel's theory for failing to encompass human diversity); see also D. Kirp, M. Yudof \& M. Franks, Gender Justice 75-81 (1986) (critiquing the notion of "strong" community as too homogeneous and totalitarian, and offering alternative vision of "open" community).

201. Cf. Minow, supra note 157 , at 160 (heightened awareness of the difference dilemma and its implications, and self-conscious reflection about the ways we think about the problem of differences, may help us arrive at new strategies for dealing with the problem, rather than perfect solutions). 
proach diverts attention from the need to ask how acknowledged differences should count and how the law should respond to the variety of differences between people. What do we make of the differences between men and women, using both, rather than just men, as a reference point? To start thinking about what the significance of a perceived difference should be, we have to question the valuation assigned to a particular difference. To do this we have to remain sensitive to the fact that the attribution of difference is one of perspective, and that the attribution is constructed out of a relationship between the "normal" and the "different," a relationship affected by the power to label.

These questions about differences represent a significant change in emphasis from the question posed by equality analysis. They move us away from an orientation toward sameness and an acceptance of the premises underlying the labels "same" and "different," to one focused on thinking about the norms or prevailing values embraced by the attribution of difference.

Thinking about the meaning of the attribution of difference means that we must constantly subject to critical scrutiny the idea of a normal standard of measurement, defined by those with the power to define. We must scrutinize structures such as job requirements and expectations, and assumptions about human capabilities, to see to what extent they are determined not by the real needs of the job or of society, but by the idea of a norm that does not actually reflect job functions or the composition of society or the workforce. For example, the prevailing norm that a worker is an able-bodied person who should rarely get sick and who has someone else who can devote full time to taking care of children, food, laundry, repairs, errands, and family illnesses, describes very few men today and even fewer women. Once the false nature of the norm around which workplaces are structured is realized, the answer to the question of "how should an employer or the law respond to the differences between men and women" starts to change. It becomes less significant that women are "not men." It can be understood that, in relationship to each other, there may be more commonalities than supposed, and that a policy adopted to respond to the needs of women can be inclusive of, and benefit men too. It also might make apparent the need to start changing the values and structures of the workplace to incorporate some of the values of the world traditionally associated with women. ${ }^{202}$

202. See J. Martin, supra note 4, at 178-86, 193-99. In writing about educational philosophy, Martin criticizes the prevailing attitude that the education of a good citizen need only focus on skills and values associated with the public world of production, rather than on skills and qualities traditionally associated with the home world of reproduction and childrearing. She argues that qualities associated with both worlds are of crucial importance to developing caring, empathetic, responsive, intellectual, and technically skilled well-rounded human beings, and that we therefore need to reconceptualize the goals of education. This same observation can be transferred to the skills and qualities valued in the workplace, where better interpersonal skills, caring, sensitivity, 
Legal discourse must also be expanded to recognize the idea that differences are not immutably fixed in certain groups across time, but rather are relative and fluctuating comparisons that depend on who is doing the comparing and by what standard. By assessing everyone against a norm, equality analysis starts from the premise that differences immutably reside in individuals. In fact, however, they reside only in the comparisons we draw to locate ourselves in relation to others:203 male-female, pregnant-nonpregnant, able to work-unable to work. Consequently, drawing lines between sameness and difference as if they were immutable categories, as equality doctrine compels us to do, is not a particularly coherent or fruitful enterprise. We could move further toward the goal of responding to social problems such as gender hierarchy if we focused not on sameness and differences, but on the conditions that have produced the problem, such as the separation of home and work and the consequent barriers for women and strictures for men. Then, we could focus on how notions of relevant samenesses and differences have been constructed to feed back into those conditions. This would enable us to start to question the social construction of, and significance assigned to, those differences.

An appreciation of the relational and constructed quality of differences can lead us away from reacting to "different" as "unequal," or "less." It also requires an enlarged view of the context in which we ask the question of how to respond to the difference. Locating a difference between men and women, such as the fact that women get pregnant and men do not, in the relationship between them and in the context of the workplace, changes our view of the significance of the difference, which should affect an employer's and the law's response. The fact that pregnancy is a "difference" between men and women does not mean that pregnancy and its consequences affect only women. Seen in this light, maternity leave may not be such a "special" right for women only, as equality analysis portrays it to be.

In order to appreciate better the relational nature of differences, legal decisionmakers will have to be encouraged to make a conscious

listening, responding, and striving for collaborative rather than competitive solutions, all may be more important for success than sheer smarts and technical training.

203. See M. Minow, supra note 172, at 27-28. Differences exist between peoplethey exist in relationship to others, rather than as a quality intrinsic to an individual. See Minow, supra note 157, at 204-05. For someone to be normal, satisfying the "sameness" criterion, there must be someone who is different who can be used in relationship to, and as a counter example to, the "normal" person. To make this point specific in the gender context, men define what it means to be a man through the other, or the opposite-woman. Men are defined as not women, and masculine traits are the opposite of feminine traits. Thus, men need women to maintain their sense of self as men. At the same time, women are defined with reference to men-as not men. But to the extent that something defined as belonging primarily to the world of women, or men, may be a valuable quality for a human being of either sex, men will have "feminine" traits, and women will have, or seek to acquire "masculine" traits. And thus the categories blur and threaten each other. 
effort to listen to and to appreciate the perspective of those they have labeled different. ${ }^{204}$ In antidiscrimination law the perspectives of the victims of discrimination have too often been ignored; the voices of women, in particular, have too often been unheard by our legal system. Because of this lack of attention to the perspectives of the "different," the concrete way in which various attributions of difference have harmed those so labeled has often been overlooked in judicial opinions. ${ }^{205}$ While it is certainly problematic for those in power, who are used to thinking of themselves as part of the norm, to put themselves within the perspective of someone they have been taught to view as different, ${ }^{206}$ simply being asked to make the effort to think in those terms can broaden one's horizons and enrich one's own perspective. Being conscious of the fact that attributions of difference are largely a matter of power and one's perspective can make us less certain that the "other" is really so different. It can help break through the barriers of distrust and misunderstanding that reinforce the idea of difference as something undesirable and deserving of penalty. This will probably require new terminology, since current preconceptions are firmly embedded in the word "different." If we start talking about varieties and nuances rather than differences, it may be easier to see the necessity and desirability of many human distinctions. It will also become less important to rank qualities or people, such as putting the feminine into a less valued home sphere, and the masculine into a more valued public sphere. It will also make us less comfortable with accepting generalizations about each gender. ${ }^{207}$

204. See Freedman, supra note 51 , at 966 .

205. Id. at 965-66; see also C. Gilligan, supra note 158 (illuminating the many ways in which the woman's voice has not been listened to or valued).

206. M. Minow, supra note 172 , at 29-30, discusses the reasons such an enterprise can be problematic and yet very important for judges:

"no one can ever really take the perspective of another; at best, one can try to imagine, from one's own perspective, the perspective of another. Yet this very impossibility at the heart of the task of taking another's perspective carries with it some benefits for judicial inquiry. It invites a certain amount of humility and self-doubt in the enterprise of trying to know. These very qualities may allow the court to glimpse a point of view other than its own or at least develop a basis for knowing that its own point of view is not the only truth."

Id.; see also Note, Expanding the Legal Vocabulary: The Challenge Posed by the Deconstruction and Defense of Law, 95 Yale L.J. 969 (1986) (fact that law is a communicative process, rather than an objective body of neutral rules, suggests that judges have an obligation to be receptive to the views of others and to be aware of the danger of complacency or self-righteousness in one's long-held views).

207. Cf. Arizona Governing Comm. for Tax Deferred Annuity and Deferred Comp. Plans v. Norris, 463 U.S. 1073 (1983); Los Angeles Dep't of Water \& Power v. Manhart, 435 U.S. 702 (1978). In striking down as inconsistent with title VII sex-differentiated contribution pay-in and benefit pay-out levels, despite the actuarially true generalization that women live longer, as a group, than men, the Court stressed the dangers in group based generalizations. Its insistence on an individualized focus in this context displays the more appreciative attitude towards human variety advocated in this Article. The 


\section{B. Incorporating the Ideal of Responsibilities Into Our Legal Discourse}

1. The Terminology of Responsibility.-It is also necessary to devise new terminology to supplement rights analysis. It may not be sufficient to think only about expanding "rights," because the word "rights" too often connotes fending off, retreating into a protected private zone. While individual protections from interference by others and the state are important for maintaining a democratic society, ${ }^{208}$ the need for freedom from interference with autonomy hardly describes the full range of human needs. The values of community and interconnection are deserving of recognition by the legal system. Accordingly, the notion of rights should be supplemented by conceptions of responsibility. I choose the term "responsibility" because the fact of interconnection between people and between various aspects of our lives such as work and home give each of us a measure of responsibility for how our actions or failures to act affect others. Responsibility means not simply honoring obligations, but responsiveness to the perspectives and needs of others. ${ }^{209}$ According to this view of responsibility, autonomy is not limited to determining one's actions through separation from others, but includes determining actions by considering others. ${ }^{210}$ For example, pregnancy and parenting policies, or the lack of them, have hurt

Court appears to view the issue as what the appropriate response should be to the fact of an apparent biological group-based difference between men and women, rather than concluding the analysis with the observation of a difference. Thus, the Court does not permit the difference automatically to penalize women. Among the reasons for being wary of relying on the generalization to penalize women in the situations presented in Norris and Manhart, are that the actuarial tables were not sufficiently sensitive to the fact that different work histories may contribute to different longevity rates, so that as between men and women working together and exposed to the same stresses, conditions, and hazards, the accuracy of the sex-based generalization may break down. In other words, what may appear at first glance to be a biologically immutable "real" difference between men and women may be partly socially, or environmentally constructed.

208. Because I think that rights as they have traditionally been defined in our society are important, I disagree with some of the more extreme criticisms of rights discourse. There is a tendency for such general critiques of rights to be insufficiently sensitive to the social context of rights claims. See, e.g., Tushnet, supra note 182 . It remains important, however, to question whether the sole aim of a political movement should be expressed in terms of winning rights and whether rights as we know them embrace the entire realm of possibilities or needs. It is also important to remain sensitive to the particular set of interests or needs that a particular right may serve to advance, so that we can examine whether another group needs to redefine or reconceive the right to fit its experience. For example, many of the rights that feminist litigators have been fighting to achieve for women have been developed with men, or blacks, in mind. Winning them thus plays into the assimilationist model. To move beyond assimilation, women must attempt to define their own needs and thus the rights that they should seek, rather than trying always to cabin women's needs and experiences into the male-defined molds. See Schneider, Rights and Politics, 61 N.Y.U. L. Rev. (forthcoming 1986) (describing how feminist litigators have referred to women's experience to formulate rights claims in areas such as reproductive freedom and sexual harassment).

209. See Feminist Discourse, supra note 135, at 44-45 (remarks of Carol Gilligan). 210. Id. 
men as well as women. So, motivated by the link between self-interest and inevitable human interactions, employers and workers of both sexes should be concerned to break down the work-family dichotomy.

The notion of responsibilities is related to but prior to conceptions of affirmative rights or communal rights. ${ }^{211}$ The responsibility that we have to others in any given situation might indicate that we should refrain from acting, and it might counsel positive action. For example, in the workplace the concept of responsibilities would start from a recognition that workers of both sexes have home lives and personal needs that affect them as workers, and that their lives as workers affect other aspects of their lives. This would give the employer a certain measure of responsibility to be sensitive to the way in which structures of the workplace can harm workers' ability to integrate their lives in a socially and personally healthy way. When we start thinking in a framework of responsibilities and interdependence, workplace policies such as parenting or caretaking leave, flexible hours, and flexible locations seem not only possible, but desirable. The idea of separate spheres of private life and work life loses its apparent validity when we approach problems from the point of view of responsibilities and interconnectedness. Moreover, when we think in terms of our responsibilities to and interconnectedness with each other, classifying someone as the same or different seems less important. Alike or not, that other person's existence nonetheless touches ours.

2. The European Model.-The response of other countries to the need for maternity and childcare leave can provide a useful model for how this country might adopt policies motivated by the perspective of interconnectedness and responsibility. Indeed, the experience in European countries demonstrates that even within societies that accept the male norm and are committed to "equality," workplace policies built on a concept of responsibilities and connections between the worlds of home and work are possible. While it is not the purpose of this Article to develop and advocate a particular maternity and parenting policy as ideal, ${ }^{212}$ the policies of some European countries illustrate a range of possibilities that employers and legal policymakers in this country could think about.

Most western and eastern European countries, building on a 1952 policy adopted by the International Labor Office (ILO), provide at least fourteen weeks of leave for women and guarantee pay and benefits dur-

211. Affirmative rights are rights phrased in terms of entitlement to something from the government, such as welfare or education, rather than as the negative right to noninterference. Communal rights recognize group interests to band together and express the needs or interests of a collectivity, such as the right to bargain collectively or to engage in worker solidarity activities. See, e.g., Lynd, Communal Rights, 62 Tex. L. Rev. 1417 (1984).

212. For creative and important works that do set out to prescribe particular policies, see Maternity Policies, supra note 9; Frug, supra note 39; Taub, supra note 40. 
ing this period equal to at least two-thirds of the woman's previous earnings. They also provide job security, or the right to return to the same or a comparable position, and guarantee paid nursing breaks when a woman returns to work. ${ }^{213}$ The ILO explains the philosophy supporting these policies as a recognition that they are necessary to make it possible for working women with families to combine their duties as mothers and workers for the good of both families and society, because maternity is a clearly recognized, important social function. ${ }^{214}$ This justification suggests an orientation toward the responsibilities perspective. At the time of the 1952 ILO convention, the woman-only focus seemed appropriate in the prevailing social context. But, as the social fabric and values have changed, more countries are starting to expand leaves to new fathers. ${ }^{215}$ Even those policies that can be faulted for challenging the ideology of separate spheres only as it affects women, ${ }^{216}$ go much further than most policies in place in this country toward recognizing that the workplace and home are not unconnected, and that employers therefore have the responsibility to make it possible for their employees to function in both realms. If leaves are also extended to men so that they can help more with the tasks of preparing for the child's arrival and caring for the newborn, workplace policies would push us much further along the goal of breaking down the home and work separation and humanizing the values and structures of the workplace.

Sweden provides the leading example of a country that requires employers to offer parenting leaves for men and women. ${ }^{21} 7$ Either the father or the mother is entitled to a leave with ninety percent of income for $\mathbf{1 8 0}$ days after the birth of a child, and either parent is then entitled to stay out of work full-time, half, or quarter time for another 180 days to care for the child, with a flat amount of income replacement during this period. This child-care leave can be used any time up through the child's first year in school. In addition, fathers are entitled to a ten day leave during the period immediately preceeding and after birth, to care for existing children while the mother is in the hospital and to help with the newborn and other children when she comes home. ${ }^{218}$ Parents of children under the age of eight may work a six hour day, and either

213. See Williams, Equality's Riddle, supra note 12, at 376.

214. Smirnov, Maternity Protection: National Law and Practice in Selected European Countries, Doc. \#ILO-W.H. 420-21 (1978), cited in Williams, Equality's Riddle, supra note 12 , at $376-77$.

215. See Maternity Policies, supra note 9 , at 145.

216. See, e.g., Williams, Equality's Riddle, supra note 12, at 376-77.

217. Although the panoply of Swedish policies is supported by an extensive social insurance system that includes national health insurance and job protection with $90 \%$ income replacement for disabled workers, it is nonetheless possible to conceive of many features of that system, especially job protected leave for both sexes, being put into place here.

218. Williams, Equality's Riddle, supra note 12, at 377-78. 
parent is entitled to time off to care for sick children, up to sixty days per year per child. ${ }^{219}$ Women use these leaves far more than men in Sweden, ${ }^{220}$ indicating that laws and policies do not change deeply embedded societal attitudes overnight. Nevertheless, both the availability of leave for men, and government encouragement of men to avail themselves of the benefits, has helped to make it possible for increasing numbers of Swedish men to participate more fully in childrearing. ${ }^{221}$

3. State Legislation and Responsibility.-Those states that require employers to grant job-protected leaves to women have taken a major step in the direction of incorporating the perspective of responsibilities into their laws. There is an important distinction between current maternity leave laws and past protective legislation that may blunt the discriminatory tendencies in the special-treatment strategy. The now discredited examples of protective legislation-restrictions on the hours or times women could work, job restrictions, height and weight restrictions, lifting restrictions-were designed to exclude women. Laws that require employers to make reasonable maternity leave available to those who want it are designed to foster the inclusion of women. The context in which these laws are being applied is also significantly different, because exclusion on the basis of sex or pregnancy, although it still occurs, is now illegal and can be challenged. Moreover, by requiring employers to provide an adequate period of leave time to accommodate the physical needs of most women, ${ }^{222}$ and by leaving the choice whether to take leave up to the individual woman, these laws go a long way toward alleviating the paradoxical problem of the usual limited leave policies, which is to either force women out of the workplace, or to force them back to work before they are ready. ${ }^{223}$ Rather than condemning policies aimed at women as "special treatment," 224 these policies can be appreciated as benefiting men and children as well as women. Moreover, even though paternity leave is an important provision to push for, it seems foolish to oppose policies that, while perhaps not going far enough toward challenging the separation of the home

219. Id.

220. Id. at $378 \&$ n. 213 .

221. Men in the United States are starting to demand the right to use leave time to care for children on the same basis as women. The fact that men are starting to ask for child care leave and that a national weekly news magazine has given recent favorable publicity to this trend, see The Real Mr. Moms, Newsweek, Mar. 31, 1986, at 52, indicates that the availability of parental leave coupled with a few male role models can start to change attitudes.

222. Longer leave than just the period of physical disability would be desirable to accommodate the emotional needs of parents and children.

223. See supra notes $17-48$ and accompanying text.

224. See Williams, Equality's Riddle, supra note 12, at 377. Available evidence about the effects of the British policies suggest that they do not hurt the employment opportunities of women and that employers' fears about excessive cost and disruption of the workforce are groundless. W. Daniel, Maternity Rights: The Experience of Employers 85 (1981); W. Daniel, Maternity Rights: The Experience of Women 113-19 (1980). 
and work spheres for both sexes, definitely provide something that women badly need. A policy that provides adequate leave for women, while not yet addressing leave for men, can be a liberating step so long as pressure continues for adopting policies that would break down the home-work separation for men, too. Indeed, as the experience in Europe illustrates, once leave for women is accepted, it may be easier to achieve leave for men.

4. Bearing the Cost of Responsibility.-Employers should bear the costs of these responsibilities because childbearing and rearing are crucially important social functions that are connected to and have major impacts on the work world. ${ }^{225}$ If the work world does not accommodate these functions, both it and society in general will suffer. Although it will hardly be cost free to expand parenting leaves in this country, employers will also benefit by having a happier, healthier, better adjusted, and more productive workforce. In addition, the costs at present may be overestimated. Companies that have instituted leave or childcare plans have found that morale and productivity of employees go up, absences are reduced, and training and replacement costs are also reduced. ${ }^{226}$ Thus policies consistent with the responsibilities approach can be compatible with the employer's needs for profit and productivity.

Historically, there have been other sorts of important social needs for which employers have long been expected to share the costs. For example, providing for people when their work days are over is an important social need; hence employers are required to participate in the costs of the social security system. Yet that system was structured with the life and work span of the typical male worker in mind. ${ }^{227}$ As an-

225. Two objections to this assertion must be addressed here. The first objection is that parenting policies would cost too much in economic terms. There are many possible ways of funding parental leave to alleviate the burden on employers, such as government funding, or joint governmental-employer insurance schemes, and employee contributions. The Parental and Medical Leave Act of 1986, H.R. 4300, 99th Cong., 2d Sess. (1986), provides for a study of the best way to fund paid leave before requiring that leave be provided with income replacement. Employers in this country could also meet with their European counterparts to learn from their experience.

The second objection is that our society's attitudes toward and lack of support for parenting is far larger than just a workplace problem, and that focus on employers will not help numerous women. While I agree that the responsibilities perspective demonstrates that we are dealing with a social problem, and not just a workplace problem, employers and their policies nevertheless remain part of the problem and thus part of the solution. I do not intend, however, to give the impression that employment policies are the sole solutions to the problems of parenting, the economic welfare of women and children, and the need to integrate the values of the productive and reproductive spheres. Among the reasons I focus on maternity in the workplace in this Article is that it presents a current controversy that illuminates the limitations of equality analysis for dealing with gender issues.

226. See Bruno \& Vehling, Day Care on the Job, Newsweek, Sept. 2, 1985, at 59-60; Lang, supra note 23, at 42-45.

227. The structure of the Social Security Act, 42 U.S.C. $§ 301$ (1982), assumed that 
other example, this nation has decided that defending the country in military service is a crucial need, and it is a task performed almost exclusively by men. Thus, we not only have systems of employment preference for veterans, ${ }^{228}$ but during World War II, the Selective Training and Service Act of 1940 required employers to protect the jobs of the men in the army and to reinstate veterans with full accrued seniority. ${ }^{229}$

When male activities and needs have been deemed socially important, employers have frequently been expected to bear some responsibility for them, even to the point of restructuring their workplace to the detriment of some other workers. Should we not expect the same for female activities and needs, especially one with such obvious social importance as bearing children? Moreover, although there are conflicts between being a parent and a worker, just as there are between being a soldier and a worker, or between becoming aged and infirm and working, we should be able to expect the workplace to alleviate some of the conflict in the first situation as well as in the others. Indeed, when we closely scrutinize which social activities have been valued in the workplace and which have been overlooked, it might not seem so anomolous to suggest that workers of either sex should be entitled to lengthy parenting leaves with job and seniority protection.

Finally, we must consider what not adopting adequate maternity and parenting policies will cost, in economic, emotional, and societal terms. The economic and social subordination of women that flows from the history of workplace incompatibility with their childbearing role has contributed to the economically and psychologically damaging phenomenon known as the feminization of poverty. ${ }^{230}$ Meeting the economic needs of working mothers is especially important today, since more women with children are in the workforce than ever before. ${ }^{231}$ The ways in which the spheres of production and reproduction have been kept apart, with few of the values of the reproductive world entering the public world, have contributed to the emotional impoverish-

most women were housewives economically dependant on their working husbands, and that women but not men had principal childcare responsibility. Cf. Califano v. Goldfarb, 430 U.S. 199 (1977) (provision of Social Security Act requiring widowers but not widows of deceased workers to prove financial dependency to qualify for benefits held unconstitutional); Weinberger v. Wiesenfeld, 420 U.S. 636 (1975) (section of Social Security Act granting to widows but not to widowers with small children benefits to enable parent to stay home held unconstitutional).

228. See, e.g., Personnel Adm'r v. Feeney, 442 U.S. 256 (1979).

229. This law and its implications for collectively bargained seniority systems are discussed in Ford Motor Co. v. Huffman, 345 U.S. 330 (1953). Many of the workers displaced when the army veterans returned to reclaim their jobs were women hired into previously all male preserves. This makes the sex biases of the veterans' job protection statute all the more apparent.

230. See H. Scott, supra note 48 .

231. See supra note 17 . 
ment of many human beings. ${ }^{232}$ The work world too rarely makes it possible to sustain qualities of cooperation, caring, gentleness, and compassion. Yet these are qualities that both men and women must develop if we wish to foster a healthy society.

5. The Limits of Responsibility Analysis.-Another important issue raised by my argument for policies that are derived from a perspective of responsibilities and the recognition of interconnectedness is how far the perspective should take us. What role remains for notions of personal privacy and a zone into which employers should not intrude? Where should the line be drawn between the human need for community and the simultaneous need for noninterference?

In approaching this issue, we must first accept that conflicts are inevitable between the need for a zone of individual freedom and the need for community. Not unique to the liberal conception of rights, this tension is endemic to the human condition. ${ }^{233}$ On one hand, "individual autonomy and community are not contradictions at all; rather, they shape and give meaning and richness to each other." 234 On the other hand, while isolation can be detrimental, too much community can be stifling or repressive, particularly if forced on individuals who might prefer to be alone or to be part of a community with different values. ${ }^{235}$ It is probably impossible to arrive at a satisfactory generalization of what the proper dividing line between individual needs for solitude and community should be. The line will vary with individuals and with time and historical context. Yet, in any given situation, if we are to arrive at a good approximation of the line, our legal system must recognize the value of interdependence and responsiblity along with the value of self-fulfillment. After all, one route to self-fulfillment is through our connections and relationships to others. The limitation of our traditional conception of rights and equality is that it slants the balance too far in the individualistic direction. A balanced conception of needs, acknowledging that human beings have both rights and responsibilities, can admit to the dynamic and contextual relationship between them. Thus, it will make us less uncomfortable with the idea that balancing solitude with community is an enterprise responsive to context and political values, rather than formal rules. Indeed, it may enable us to reconceive what making a decision between these needs means. Rather than every decision being an either-or choice, there may be options that satisfy both values, given their interdependent nature. ${ }^{236}$

232. Cf. J. Martin, supra note 4 (to develop well-rounded human beings, education should cover both productive and reproductive spheres).

233. See Sparer, supra note 150 , at $518 \mathrm{n} .21,547-52$.

234. Id. at 547.

235. Women have often been victims of "forced community" due to their economic and legal dependence on men and the constraints of the social and sexual roles thought to be appropriate for them. See Olsen, supra note 112, at 430 .

236. Carol Gilligan has noted the tensions between the voice of "equality, reciprocity, fairness, rights," and the voice that "speaks about connection, not hurting, care and 
For example, when an employer reaches across the public-private line by offering parenting leaves, the policy accommodates individual choice and also makes possible a richer kind of self-fulfillment by enhancing connection. On the other hand, policies that condition being hired or retaining a job on having or not having certain personal habits can impede personal autonomy with little compensating gain for making the workplace more responsive to values traditionally associated with the home sphere. In other words, the point of the responsibilities framework is hardly to obliterate all conceptions of privacy in the workplace, but rather to make it possible for people to combine various facets of their lives in a more satisfying way.

Although the responsibilities perspective might sound like a fancy justification for paternalism, with its dangers of the intrusive abuse of power, ${ }^{237}$ the concept rests on a very different notion of the use of power. Paternalism usually means protecting people from themselves, with the protector exercising the judgment about what those in need of protection should really want or should really do for their own good. ${ }^{238}$ Policies that come out of the perspective of responsibility, on the other hand, are meant to respond to another's needs. The idea of response connotes unity and empathy-intersubjectivity, rather than the subjectivity of traditional paternalism. ${ }^{239}$ Lest the idea of responsibility descend into a subordinating kind of paternalism, it will be important for

response." She has observed that an approach which seeks to include the two voices is not simply an androgynous, or separate but equal, solution, but rather, represents a radical transformation in thinking. Feminist Discourse, supra note 135, at 44-45. Her work suggests two examples of this way of transforming problems. She recounts the story of two children, a boy and a girl, who were deciding what game to play. The boy wanted to play pirates, and the girl wanted to play neighbor. Rather than resolving the conflict by the seemingly fair, or androgynous approach of doing both-playing one game for a while and then switching to the other, the girl suggested that they play "the pirate who lives next door." This new game transformed both, putting the pirate into a relationship-based context. Id. at 45-46. In her book In a Different Voice, supra note 158, at 27-31, she tells the story of Amy, who, when asked whether a poor man should steal a life-saving drug for his dying wife, refused to force the problem into a hierarchy of the right to life over the right to property. Rather, she enriched the context and transformed the discourse about both rights by considering the various relationships involved-druggist, husband, wife-and the effect on each of stealing and its consequences. This led her to see other ways of resolving the various needs besides stealing.

In the context of workplace policies, if we stop looking for conflicts and hierarchies of individual interests and needs, such as the employer's right to property versus the worker's right and need to have a family, we may similarly be able to transform our thinking about the possible responses and the way in which they will affect the ongoing relationships of employer-employee, employee-employee, husband-wife, and parentchild.

237. See Kennedy, Distributive and Paternalist Motives in Contract and Tort Law, With Special Reference to Compulsory Terms and Unequal Bargaining Power, $41 \mathrm{Md}$. L. Rev. 563, 588-89, 647-48 (1982).

238. Id. at 572,588 .

239. Id. at $642-49$. Kennedy defends the idea of paternalism because it too can reflect empathy, love, and intersubjectivity. 
decisionmakers to remain sensitive to the perspectives of those affected by their actions. The same sort of sensitivity to perspective that can mediate the oppressive tendencies of the idea of differences-appreciating that what one considers normal is infused with one's own perspective-can serve as a restraining influence on the paternalistic tendencies of a relationship-based mode of dealing with problems. ${ }^{240}$

\section{How Responsibilities Analysis Transcends the Limits of Equality Doctrine}

Adopting the suggested approaches to differences and human interconnection can free legislators and lawyers to construct many policies that make sense in terms of human needs and responsibilities, but that might be impermissible under strict equality analysis or concern over sameness-difference comparisons. Examples of desirable policies might include maternity leave, paternity leave, child or dependant care leave, flexible scheduling or adjustments in break time for those who are breast feeding or who have to pick up children from school or day care, and flexibility in defining expected performance so that suitable types of work can be done at home or at untraditional hours. Undue concern for thinking in equality terms could hamper these developments, because it will always be possible to find a comparison group that might be disadvantaged by any given policy. ${ }^{241}$ For example, it can be argued that parental leave policies, in effect, require the old, and the childless, to subsidize the reproductive behavior of others. Similarly, allowing flexible scheduling for women workers who are breastfeeding

240. Id. at 648-49. As Kennedy observes:

The farther apart they are culturally, the more likely it is that the actor will perceive "mistakes" or false consciousness on the part of the others that they won't recognize as such no matter how much data he lays on them, because they involve basic premises about the world, truth, and the good. . . . [But a] decisionmaker who will not take the risk of imposing housing codes and then enforcing them through tenant remedies . . . because he doesn't feel confident about what the poor "really want," has let a constituent group slip outside his capacity for intimate intuitive knowledge .... [The decisionmaker is] almost certainly a middle or upper middle class person, or a person who identifies with those classes in his heart. If he is concerned about failures of intuition, about the limits of empathy, he has two alternatives .... The first is to investigate the consciousness of those he isn't supposed to mess with. This means breaking down the barriers of segregation by knowing others, rather than just making rules for them. The second is to go beyond the exploration to the task of helping mobilize the groups on whose part one may have to act paternalistically. So long as one is a decision maker playing God with the lives of people of other races and classes and sexes, the dilemmas of ad hoc paternalism are inescapable. The only way to reduce the risk of making mistakes for which one is responsible no matter how good one's intentions is to deal with people who are not at a great distance, who are not strangers ....

241. Although many of these comparison groups will not be protected under title VII or the Constitution, this does not blunt the observation that concern about comparative equal treatment may deflect attention from the social policy issues that should be the focus of concern. 
could be seen as discriminating against men and women without infants who may need flexibility to meet other personal needs.

The point here is not to set out the details of a brave new world of the responsible workplace, but to underscore the implication of the responsibilities analysis: the legal system's approach to policies designed to chip away at the notion of home and work as separate spheres should proceed according to an analysis of what people need and what is important in light of the interconnection between home and work. Policymakers should seek to avoid getting embroiled in the limitations of equality-type arguments about comparisons between ever-varying categories and about clashing individualistic rights.

But, the question remains whether it is possible to begin thinking in terms of responsibilities and interconnectedness within the confines of a judicial system dominated by the perspective of individualistic equality and rights of noninterference. Change may occur initially in the legislative or workplace arenas, because these forums can be more receptive to arguments based on desirable social policies that flow from appreciating interdependence than the litigation arena, where problems are crystallized into disputes that then must be fit into the procrustean bed of comfortable doctrinal frameworks such as equality analysis. Indeed, signs of significant progress have appeared in the form of proposed parental leave legislation ${ }^{242}$ and a trend toward liberalized parenting leave for men as well as women among major corporations. ${ }^{243}$

Nevertheless, the courtroom world of legal doctrine will not be resistant to change if, while using the given language of equality and rights, lawyers enlarge their dialogue beyond a comparison-oriented search for samenesses and differences. It will be necessary to talk explicitly about the social and historical context of the problem-about the effects of moral and legal choice on real people. It will be necessary to discuss openly the political value choices underlying each contending view - the implications of the dispute should not be obscured beneath a veneer of supposedly neutral, apolitical equality doctrine. Finally, it will be necessary, in framing one's arguments to raise questions about whether the norm that informs equality theory reflects human variety, to reexamine the ideal of assimilation and to attempt to bring in the perspective of the "other" in order to remind the decisionmaker that his or her view is not the only perspective. ${ }^{244}$

242. The Parental and Medical Leave Act, H.R. 4300, 99th Cong., 2d Sess. (1986), discussed supra note 121 and accompanying text. This bill has received enthusiastic support in the congressional hearings held thus far. Unpaid Leave for Parents Supported at Joint House Comm. Hearing, Govt. Empl. Rel. Rep. (BNA) No. 23, at 1505-06 (Oct. 21, 1985); Parental Leave Advances in House, Govt. Empl. Rel. Rep. (BNA) No. 24 , at 833 (June 16, 1986).

243. See Catalyst, supra note 9 , at 5 (June 1984).

244. To avoid having existing equality analysis such as that embodied in title VII 


\section{ConClusion}

While equality analysis has been vastly important for women, and has enabled us to eradicate many blatant examples of unfounded and unjustly stereotyped differential treatment, it is fundamentally flawed as a means for dealing with the systemic and more subtle gender subordination that we must confront now that the easy cases have been won. Equality analysis is particularly ill-suited for issues of gender differences that appear biologically based, such as childbearing, because it is predicated on a search for sameness. Yet, because pregnancy is in many significant respects different, its similarities to other human conditions can be permanently elusive to legal decisionmakers. Even more problematic for its application to gender issues, however, is the fact that equality analysis is inherently male-biased. The search for sameness is built around male norms, so that what is male is the standard for measurement. For women, the application of equality analysis means that so long as women are just like men, or are willing to ascribe to male values and standards, the law will assist them in doing so. But, where women appear to be truly different from men-in their capacity

serve as a preemptive barrier to responsibility-oriented legislative initiatives, sensitivity to historical and political context will be important in any given case to try to make apparent the sex-based discrimination and stereotyping lurking behind the traditional lack of attention by employers and society to needs emanating from the home sphere. For example, in the case that sparked the equal treatment/special treatment debate, California Fed. Sav. \& Loan v. Guerra, 758 F.2d 390 (9th Cir. 1985), cert. granted, 106 S. Ct. 783 (1986), which will decide whether the California maternity leave law is preempted by title VII, reminding the Court of the full context may enable the state statute to survive preemption analysis by demonstrating the similarity of the evils being addressed by the challenged law and by title VII. The full context includes the fact that women have traditionally lost their jobs because of pregnancy, that most children today will either be reared in families where both parents work and are dependent on two incomes, or by single women, that maternity leave provisions in this country continue to lag far behind the rest of the world, and that this situation has a real detrimental impact on families, on children, on the economic position of women, and on the roles available to both men and women. The issue could then be framed as whether title VII was meant in any way to prevent a state from responding to these problems that have traditionally adversely affected women by requiring employers to be more responsive to the needs and actual lives of their workers. The issue becomes one of the appropriateness of acting out of the perspective of responsibility, rather than one of equal treatment or special treatment. In response to the anticipated objection that the way the state has responded requires discriminatory special treatment for women, one could point out the limiting assumptions of that way of looking at the issue. The maternity leave law does not discriminate against men and the nonpregnant, but rather provides much needed economic protection for fathers and children, as well as for pregnant workers. This line of response might serve to remove the debate from the trap of equality theory to the more productive level of focusing on what employers should do once we accept the idea that they bear some responsibility for the integrated home and work lives of their employees. The issue then becomes whether a state can require an employer to proceed one step at a time along the path of responsibility, by responding only to childbearing for the time being, or whether it is legitimate only to make the whole leap at once to a workplace that responds to all areas in which workers need more accommodation for human needs. 
to become pregnant and their traditional relegation to the sphere of childrearing - they may be legally penalized in the public sphere of the workplace for not being men. Equality analysis is of little use to women who would like to question the male-oriented values and norms upon which the workplace is built.

The trap that equality analysis has become for women in the seemingly unique context of pregnancy highlights the need for a new conception for evaluating gender issues. Any approach, to be adequate, must not mask, as equality analysis does, the deeper underlying aspects of the value choices and the vision of society at stake in debates over gender roles. We need a legal framework that offers a richer conception of human needs than the theory of human nature that undergirds equality analysis. Such a framework must perceive not only our essential interconnectedness, but must start from the premise that work and family are the two most important defining aspects of the lives of men and women. Consequently, the idea that these two aspects of human existence occupy separate spheres must be replaced with legal policies and a framework for evaluating them that appreciates that public and private are a continuum, with each defining and affecting the other. If we supplement our existing conception of rights with a concept of responsibility to others arising out of our interconnectedness, we can begin to move toward workplace policies that make it possible for both women and men to combine their work lives with involvement in the family. Maternity leave laws should be understood as examples of such policies, because rather than being "special treatment" for women, they redound to the benefit of men and children, as well. 